Original research article

Nutritional Research Section

\title{
Effects of Four-Week Intake of Blackthorn Flower Extract on Mice Tissue Antioxidant Status and Phenolic Content
}

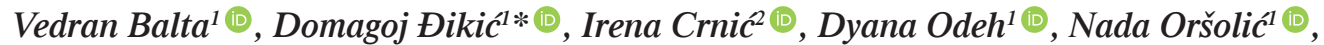

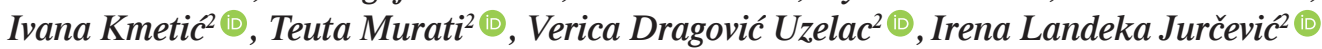 \\ ${ }^{1}$ Faculty of Science, University of Zagreb, Rooseveltov trg 6, 10000 Zagreb, Croatia \\ ${ }^{2}$ Faculty of Food Technology and Biotechnology, University of Zagreb, Pierottijeva 6, 10000 Zagreb, Croatia
}

Key words: pharmacokinetic, flavan-3-ol, flavonoids, bioavailability, phenolic compounds, Prunus spinosa L.

The study examined the antioxidative physiological effects of phenolics from an ethanol-water extract of blackthorn flowers orally administrated to C57/BL6 mice for 28 days in daily doses of $25 \mathrm{mg}$ of total phenolics/kg body weight. Contents of phenolics in the intestine, liver, and kidneys collected after 1, 7, 14, 21, and 28 days of extract administration were analyzed by UPLC-MS/MS method. In the same tissues, the antioxidative properties were determined as ferric reducing antioxidant power (FRAP), ABTS ${ }^{\cdot+}$ scavenging activity, content of reduced glutathione (GSH), and activity of superoxide dismutase (SOD) and catalase (CAT). The lipid peroxidation in tissues was also evaluated by thiobarbituric acid reactive substances (TBARS) assay. The exposed mice (compared to the control ones) had a lower content of TBARS in all tissues mostly on the third/fourth week of daily consumption. SOD activity and GSH content increased on the $28^{\text {th }}$ day in tissues. CAT activity was higher only in the liver after one week of consumption but remained unchanged in other organs throughout the experiment. Phenolic profiles were different in individual tissues. The most prominent increases compared to the control were determined for contents of 3-O-feruloylquinic acid, 4- $O$ - $p$-coumaroylqiunic acid, kaempferol pentoside, and quercetin rhamnoside in the intestine; for ferulic acid and quercetin 3-O-rutinoside in the liver; and for quercetin 3-O-rutinoside, ferulic acid, and 4- $O$ - $p$-coumaroylquinic acid in the kidneys. The screened phenolics with different distribution in tissues could be responsible for slight differences in the recorded antioxidative effects.

\section{INTRODUCTION}

Blackthorn (Prunus spinosa L.) is a perennial shrub belonging to the rose family (Rosaceae), growing throughout Europe, western Asia, and northwest Africa [Elez-Garofulić et al., 2018]. Recently, blackthorn has become interesting both industrially as a food plant and pharmacologically as a nutraceutical or a medicinal plant because it is a rich source of phenolic compounds [Meschini et al., 2017; Mikulic-Petkovsek et al., 2016; Pinacho et al., 2015; Yuksel, 2015]. The fruits of blackthorn, known also as the "sloe", are small round with black skins covered in a blue waxy bloom and extremely acid-tasting, and must be thermally processed prior to consumption. They are used for jams, liqueurs, wines, juices, compote, and tea production. Blackthorn flowers, bark, and root have been traditionally used in folk medicine for diuretic and laxative properties, due to their abilities to remove excess sodium ions and harmful products of metabolism, to reduce blood vessels permeability, and against inflammation of the urinary tract [Elez-Garofulić et al., 2018]. In western and northern Europe and Mediterranean countries, fruits were traditionally consumed but consumption declined in the $20^{\text {th }}$ cen-

\footnotetext{
* Corresponding Author: Tel.: 00385915898159

E-mail: magistar_djikic1@yahoo.com (D. Đikić)
}

tury [Alarcón et al., 2015; Menendez-Baceta et al., 2012]. There is archaeological evidence that fruits were consumed in distant past as well. In the book on palaeoethnobotany of the prehistoric food plants of the Near East and Europe, the blackthorn seeds are mentioned as leftover of fruits that have been found and recovered in a number of European prehistoric sites from the neolithic and iron age, sometimes in large quantities (in barrels) [Renfrew, 1973].

Mikulic-Petkovsek et al. [2016] compared the phenolic and other secondary metabolite contents of various Prunus spp. wild fruits and concluded that the blackthorn (P. spinosa) showed richness of various plant phenolics making it a good candidate species among the genus Prunus spp. for the studies of phenolic biological activity upon consumption. Although berries are traditionally consumed, other plant parts such as flowers were studied for the content of phenolics as well. For example, a study of various morphological parts of blueberries (Vaccinium angustifolium L.) and lingonberries (Vaccinium vitis-idaea $\mathrm{L}$.) has found that the leaves have a much higher phenolic content and antioxidant capacity than fruits [Kelly et al., 2017]. Olszewska and her co-authors were among the first who recorded the abundance of phenolics in P. spinosa leaf and also in the flower extract [Olszewska et al., 2001; Olszewska \& Wolbiś, 2001, 2002]. Marchelak et al. [2017] reported that blackthorn flower extract contained 
total phenolics up to $584.07 \mathrm{mg} / \mathrm{g}$ of dry weight (dw). Likewise, similar studies in $P$. spinosa flowers were done by Elez-Garofulić et al. [2018] and Lovrić et al. [2017], confirming the richness of phenolics and the antioxidative properties of the flower extract in vitro. However, although this plant phenolic extracts are recently scientifically examined, those experiments describing bioactivity (antioxidative properties and similar physiological modulations) were done mostly under in vitro conditions. In vitro studies showed that the phenolics from blackthorn extract were potent antioxidants that scavenged $\mathrm{DPPH}^{\bullet}$, reduced ferric ions, and inhibited linoleic acid peroxidation and pro-inflammatory enzymes (lipoxygenase and hyaluronidase) activity, as well as effectively protected the isolated human plasma (outside the body, in vitro) against peroxynitrite-induced damage by reducing levels of oxidative stress biomarkers: 3-nitrotyrosine, lipid hydroperoxides and thiobarbituric acid-reactive substances (TBARS) [Marchelak et al., 2017]. Authors proposed the hypothesis concluded from in vitro results that the blackthorn extract might enhance the total antioxidant bioactivity if administrated within the organism. There are also in vitro antitumor assays as well as a study conducted by our group where the flower extract showed promising antitumor results $[\mathrm{Mu}-$ rati et al., 2019].

Based on the described in vitro evidence and lack of in vivo data, we have previously also conducted the preliminary in vivo study by applying only a single acute dose of the blackthorn flower extract in mice to establish whether the phenolics can be absorbed via the gastrointestinal system. A significant concentration of phenolics was found in plasma of animals after $24 \mathrm{~h}$, indicating their good gut absorption [Đikić et al., 2018]. Based on those results of blood pharmacokinetic study [Đikić et al., 2018], indicating that the number of phenolics are being absorbed, we set foundations for this 28-day consumption study and evaluation of the antioxidative activity in the organs (intestine, liver, kidney). We wanted to establish, whether mice tissue antioxidative defense markers change due to the subchronic (28 day) intake of blackthorn flower extract.

\section{MATERIALS AND METHODS}

\section{Chemicals and standards}

HPLC grade formic acid and acetonitrile were purchased from BDH Prolabo, VWR (Lutterworth, England). The following commercial phenolic compound standards: quercetin 3-O-glucoside, kaempferol 3-O-rutinoside, caffeic acid, gallic acid, ferulic acid, chlorogenic acid, and $p$-coumaric acid were purchased from Sigma-Aldrich (Steinheim, Germany). The (+)-catechin, (-)-epicatechin, (-)-epicatechin 3-gallate, (-)-epigallocatechin 3-gallate, apigenin, and luteolin were purchased from Extrasynthese (Genay, France) and quercetin 3-O-rutinoside from Acros Organics (Thermo Fisher Scientific, Geel, Belgium). Horse heart cytochrome C (type VI), human blood superoxide dismutase (SOD; type I, lyophilized powder, $2400 \mathrm{U} / \mathrm{mg}$ protein), xanthine and xanthine oxidase (200 U/mL), Ellman reagent (5,5'-dithiobis-(2-nitrobenzoic acid); DTNB), NADPH, glutathione reductase and hydrogen peroxide (30\%) 2,2'-azinobis (3-ethylbenzothiazoline-6-sul- fonic acid) (ABTS), and 2,4,6-tripyridil-s-triazine (TPTZ) were all purchased from Sigma-Aldrich. Deionized water of Milli-Q quality (Millipore Corp., Bedford, USA) was used throughout the experiment.

\section{Preparation and analysis of blackthorn flower extract}

The samples of dry blackthorn flowers were bought from Suban Ltd. company (Samobor, Croatia), a certified collector and producer of medicinal plants, and were part of the batch number 63451. The preparation of the blackthorn flower extract (ethanol/water extraction with microwave assistance) was described in detail by Elez-Garofulić et al. [2018] and Lovric et al. [2017]. We have utilized the described methods because they yielded the best extraction of phenolics and proved $50 \%(\mathrm{v} / \mathrm{v})$ ethanol/water used as a solvent to be safe for mammalian (mice) consumption in comparison to the other organic solvents which might remain as residues. For the in vivo experiment, the total phenolic (TP) content was analyzed in the original ethanol/water extract. The TP content of blackthorn flower extracts was determined using the method with the Folin-Ciocalteu reagent previously reported by Lovric et al. [2017]. A volume of $100 \mu \mathrm{L}$ of the extract (5-fold diluted) was mixed with $200 \mu \mathrm{L}$ of the Folin-Ciocalteu reagent and $2 \mathrm{~mL}$ of distilled water, and after $3 \mathrm{~min}, 1 \mathrm{~mL}$ of $20 \% \mathrm{Na}_{2} \mathrm{CO}_{3}$ was added. This mixture was incubated at $50^{\circ} \mathrm{C}$ for $25 \mathrm{~min}$. The absorbance was measured at $765 \mathrm{~nm}$ using a spectrophotometer (model UV-1600PC; VWR International, Leuven, Belgium). The blank contained $100 \mu \mathrm{L}$ of the solvent used for extraction instead of the extract. The TP content was calculated according to the gallic acid standard calibration curve, and expressed in $\mathrm{mg}$ of gallic acid equivalents (GAE) per mL of extract. The TP content of original extract was $0.5 \mathrm{mg} \mathrm{GAE} / \mathrm{mL}$. The extract was further evaporated under reduced pressure at $45^{\circ} \mathrm{C}$ to remove ethanol and concentrate the solution of polyphenolics. Before application to the mice, the concentrated solution was re-dissolved and further diluted with water to achieve the final applied solution with removed alcohol suitable for use in a dose of $25 \mathrm{mg}$ TP GAE/kg body weight of mice (this water-based working solution for mouse doses, was applied in the volume of $0.2 \mathrm{~mL}$ per mouse weighing on average 30 grams). The phenolic composition of blackthorn flower extract and details of the UPLC-MS/MS method used for its determination were shown in our previous study [Đikić et al., 2018; Elez-Garofulić et al., 2018]. It was reported that the highest concentrations were detected for 3-O-caffeoylquinic, 3-O-p-coumaroylquinic, and 3-O-feruloylquinic acid among phenolic acids; then for $(+)$-catechin and (-)-epicatechin among flavan-3-ols; and finally for kaempferol glycosides (kaempferol pentoside and kaempferol rhamnoside) and quercetin glycosides (quercetin 3-O-rutinoside, quercetin pentoside, and quercetin rhamnoside) among flavonols.

\section{Experimental animals and husbandry, study design in vivo}

For this experiment, a total of 50 male inbred C57BL/6 mice, weighing $30 \pm 1.5 \mathrm{~g}$ were obtained from the Department of Animal Physiology, Faculty of Science University of Zagreb, Croatia. Animals were fed a standard laboratory 
diet, tap water ad libitum, and received $12 \mathrm{~h}$ of light per day. The standardized diet was 4 RF 21, Mucedola (Settimo Milanese, Italy). The composition of standardized pellet mouse feed included wheat, wheat straw, hazelnut skins, maize, soy bean hulled, corn gluten feed, fishmeal, dicalcium phosphate, sodium chloride, whey powder, soybean oil, yeast; and contained $12 \%$ moisture, $18.5 \%$ protein, $3 \%$ fats, $6 \%$ crude fibers, $7 \%$ crude ash, E672 (vitamin A), E671 (vitamin E), E1 (Fe), E2 (I), E3 (Co), E4 (Cu), E5 (Mn), and E6 (Zn). Phenolic content of Mucedola feed pellets was analyzed in our previous study and results are given in Đikić et al. [2018]. The analysis revealed that all phenolic compounds that were detected in Mucedola standard mouse feed were in substantially lower contents than in the blackthorn flower extract [Đikić et al., 2018].

\section{Bioethical standards in animal husbandry and experimental protocol}

Maintenance and care of all experimental animals was performed according to the guidelines applicable in the Republic of Croatia [NN 55/2013]. The experimental procedures were approved by the Bioethics Committee of the Faculty of Science, University of Zagreb [Bioethic approval, 2014] and were conducted according to the Guidelines on in vivo experiments and accepted and international standards on the Guide for the care and use of laboratory animals [2011].

\section{Treatment groups and doses}

Animals were randomly divided according to treatment into two separate groups, namely the control group and the blackthorn flower extract group. Within those two groups, the subgroups were formed based on the time of sacrifice post treatment. Animals from both control or blackthorn flower extract groups were sacrificed on the day 1, 7, 14, 21 , and 28 post treatment (the subgroups). Each subgroup contained 5 animals. Saline for the control and blackthorn flower extract for the exposed group were administered daily as a single oral dose for the period of 28 days by gavage in a volume of $0.2 \mathrm{~mL}$ per animal. Treatment of all animals took place between 8-10 a.m. in order to equalize circadian differences between treatments and avoid differences in metabolism. The blackthorn flower extract-treated groups were dosed $25 \mathrm{mg}$ of TP of blackthorn extract per kg of body weight of mice (mg TP/ $/ \mathrm{kg} \mathrm{bw}$ ). The dose was derived from pilot experiments.

\section{Tissue preparation}

At designated experimental days for organ collection, animals were anesthetized by halothane and perfused through with $10 \mathrm{~mL}$ of phosphor buffer saline (PBS) and sacrificed by cervical dislocation, $24 \mathrm{~h}$ after the last administered dose on the particular day of experiment. Intestine, liver, and kidneys were extracted. Such tissue samples were used for antioxidative activity assays and for the determination of individually bioaccumulated phenolics by the UPLC MS/MS method. Prior to the measurement of antioxidative parameters and UPLC-MS/MS analysis, the tissue samples were placed in $50 \mathrm{mM}$ phosphate buffer $(\mathrm{pH}=7.4)$ and homogenized ( $10 \%$ of homogenate, by tissue mass per volume of PBS) with an ultrasonic homogenizer (SONOPLUS Bandelin HD2070, Bandelin Electronic GmbH \& Co KG, Germany) using an MS73 probe (Bandelin, Electronic GmbH \& Co KG Germany). Thereafter, homogenates were sonicated on ice for $30 \mathrm{~s}$ in three 10 -s intervals, centrifuged at $20,000 \times \mathrm{g}$ for $15 \mathrm{~min}$ at $4^{\circ} \mathrm{C}$, and immediately frozen at $-80^{\circ} \mathrm{C}$ until analysis. Further details of supernatant treatment for antioxidative activity determination or UPLC-MS/MS analysis are described in each section separately.

\section{Antioxidant status of tissues}

Tissue supernatant samples that were stored until analysis as described in the above section were slowly thawed at $+6^{\circ} \mathrm{C}$ on cooling pads until liquid again. Afterwards, they were centrifuged at $20,000 \times \mathrm{g}$ for $15 \mathrm{~min}$ at $4^{\circ} \mathrm{C}$. The supernatants of the centrifuged tissue homogenates were further used for analysis of ferric reducing antioxidant power (FRAP), ABTS •+ scavenging activity, TBARS content, CAT and SOD activity, and GSH content following protocols described below.

\section{Determination of the ferric reducing antioxidant power of tissues}

The FRAP assay for tissue homogenates was conducted according to Katalinic et al. [2005] method adopted for animal organs and modified from the assay by Benzie \& Strain [1996]. The FRAP reagent was prepared from $5 \mathrm{~mL}$ of a TPTZ solution $(10 \mathrm{mM})$ in $\mathrm{HCl}(40 \mathrm{mM})$ and $5 \mathrm{~mL}$ of an $\mathrm{FeCl}_{3}$ solution $(20 \mathrm{mM})$ mixed with $50 \mathrm{~mL}$ of an acetate buffer $(0.3 \mathrm{M}, \mathrm{pH}=3.6)$. Such freshly prepared FRAP reagent $(1.5 \mathrm{~mL})$ was mixed with $200 \mu \mathrm{L}$ of water and $50 \mu \mathrm{L}$ of the tissue sample or as a blank standard sample with $50 \mu \mathrm{L}$ water, and incubated for $4 \mathrm{~min}$ at room temperature. After 4 min of incubation, the absorbance was measured at $\lambda=595 \mathrm{~nm}$ with a Libro S22 spectrophotometer (Biochrom Ltd. Cambridge, UK). The results of the ferric reducing ability of the tissue homogenate were calculated according to the standard curve and expressed as nmol $\mathrm{Fe}^{2+}$ per mg of protein in a tissue homogenate.

\section{Determination of the antioxidant capacity of tissues by ABTS assay}

The ABTS assay for tissue homogenates was conducted according to Katalinic et al. [2005] method adopted for animal organs and modified from assay by Re et al. [1999]. The volume of $20 \mu \mathrm{L}$ of the tissue supernatant was mixed with $2 \mathrm{~mL}$ of an $\mathrm{ABTS}^{\cdot+}$ solution and after 6 min of incubation, the absorbance was measured at a wavelength of $734 \mathrm{~nm}$ with a Libro S22 spectrophotometer (Biochrom). The $\mathrm{ABTS}^{\cdot+}$ solution was prepared by oxidizing the $7 \mathrm{mM}$ $\mathrm{ABTS}^{\cdot+}$ solution with a freshly prepared $140 \mathrm{mM}$ potassium peroxydisulfate solution mixed in equal proportions. On the day of analysis, the solution was diluted with PBS ( $\mathrm{pH}$ 7.4) and incubated at $30^{\circ} \mathrm{C}$ so that the absorbance of this solution was $0.700( \pm 0.020)$. As a blank samplefree mix without tissue sample, a $1 \mathrm{~mL}$ of $\mathrm{ABTS}^{\cdot+}$ solution and $20 \mu \mathrm{L}$ phosphate buffer was used and the mix of ABTS ${ }^{\cdot+}$ solution with tissue sample was compared to it. The results are expressed as nmol Trolox equivalents per mg of protein in the tissue homogenate. 


\section{Markers of tissue oxidative stress defense systems}

\section{Protein concentration in tissues}

Protein concentration in the samples was determined with the method of Lowry et al. [1951], with bovine serum albumin (BSA) used as the standard. Protein concentration in tissue samples was used to express the values of the measured oxidative stress parameters (TBARS, FRAP, $\mathrm{ABTS}^{\bullet+}$, SOD, and CAT).

\section{Lipid peroxidation in tissues}

Lipid peroxidation was determined by measuring the content of TBARS using a modified method of Ohkawa et al. [1979] described in Landeka Jurčević et al. [2017]. A centrifuged sample of $200 \mu \mathrm{L}$ of the homogenized tissue was mixed with $200 \mu \mathrm{L}$ of $8.1 \%$ sodium dodecyl sulphate (SDS), $1.5 \mathrm{~mL}$ of $20 \%$ acetic acid $(\mathrm{pH}=3.5)$, and $1.5 \mathrm{~mL}$ of $0.81 \%$ thiobarbituric acid, and incubated at $95^{\circ} \mathrm{C}$ for $60 \mathrm{~min}$. After cooling on ice, the absorbance was measured at 532 and $600 \mathrm{~nm}$ with a Libro S22 spectrophotometer (Biochrom). The total absorbance was determined using the formula:

$\mathrm{A}_{\text {total }}=\mathrm{A}_{532 \mathrm{~nm}}-\mathrm{A}_{600 \mathrm{~nm}}$

TBARS levels were determined using the molar absorption coefficient for malondialdehyde-thiobarbiturate (MDA-TBA) complex of $1.56 \times 10^{5} \mathrm{M}^{-1} \mathrm{~cm}^{-1}$ and expressed as nmol $/ \mathrm{mg}$ protein of tissues homogenate.

\section{Superoxide dismutase activity in tissues}

The SOD assay is a modification of the method by Flohé \& Ötting [1984] described in Landeka Jurčević et al. [2017]. An undiluted sample of the tissue homogenate $(25 \mu \mathrm{L})$ was mixed with $1.45 \mathrm{~mL}$ of a reaction solution (cytochrome $\mathrm{C}$, $0.05 \mathrm{mM}$; xanthin, $1 \mathrm{mM}$ mixed in a $10: 1(\mathrm{v} / \mathrm{v})$ ratio with DTNB). A volume of $20 \mu \mathrm{L}$ of xanthine oxidase $(0.4 \mathrm{U} / \mathrm{mL})$ was added to start the reaction. The absorbance of the reaction mixture was measured at $550 \mathrm{~nm}$ over 3 min with a Libro S22 spectrophotometer (Biochrom). One unit of SOD activity was defined as the amount of enzyme required to achieve 50\% inhibition of superoxide anion formation within the sample which was started by the reaction of xanthine oxidase. The results were expressed as units per mg of protein in tissue homogenate (U/mg protein).

\section{Catalase activity in tissues}

The CAT activity was assayed by measuring the initial rate of $\mathrm{H}_{2} \mathrm{O}_{2}$ degradation according the method modified from Aebi [1984] and described in Landeka Jurčević et al. [2017]. The reaction mixture was prepared by mixing $33 \mathrm{mM} \mathrm{H}_{2} \mathrm{O}_{2}$ in $50 \mathrm{mM}$ phosphate buffer, $\mathrm{pH}=7.0$. This reaction mixture $(900 \mu \mathrm{L})$ was mixed with the supernatant of the tissue homogenate $(100 \mu \mathrm{L})$. The absorbance was measured at $240 \mathrm{~nm}$ for 3 min using the Libro S22 spectrophotometer (Biochrom). The CAT activity was calculated using the molar absorption coefficient of $43.6 \mathrm{M}^{-1} \mathrm{~cm}^{-1}$ for $\mathrm{H}_{2} \mathrm{O}_{2}$. The results were expressed as $\mathrm{U} / \mathrm{mg}$ protein.

\section{Reduced glutathione in tissues}

The reduced glutathione (GSH) assay is a modification of the method first described by Tietze [1969] and then in Landeka Jurčević et al. [2017]. In a 96-well plate, $40 \mu \mathrm{L}$ of $10 \mathrm{mM}$ DTNB (Ellman's Reagent) was mixed with $20 \mu \mathrm{L}$ of the tissue supernatant (obtained as described above) pretreated with $40 \mu \mathrm{L}$ of $0.035 \mathrm{M} \mathrm{HCl}$, incubated for $10 \mathrm{~min}$. Then, $100 \mu \mathrm{L}$ of the reaction solution prepared earlier by mixing $9980 \mu \mathrm{L}$ of $0.8 \mathrm{mM}$ NADPH and $20 \mu \mathrm{L}$ of glutathione reductase, $0.2 \mathrm{U} / \mathrm{mL}$, was added and the absorbance was read at $412 \mathrm{~nm}$ every minute for $5 \mathrm{~min}$ in an ELISA plate reader (Biorad Laboratories, Hercules CA, USA). The GSH levels were determined from the calibration curve of GSH standards. The results are expressed as $\mu \mathrm{M} / \mathrm{mg}$ proteins.

\section{Determination of the phenolic content in tissues}

\section{The UPLC-MS/MS analysis of phenolics in the tissues of mice post-sacrifice}

The qualitative and quantitative analysis of individual phenolic compounds in mice tissues was performed with the Ultra High Performance Liquid-Chromatography Tandem Mass Spectrometry (UPLC-MS/MS). The methods are described in detail (with respective standard curves) by Elez-Garofulić et al. [2018]. Briefly, the Agilent 1290 UPLC system (Agilent Technologies, Santa Clara, CA, USA) with the Zorbax Eclipse Plus C18 column $(100 \times 2.1 \mathrm{~mm}, 1.8 \mu \mathrm{m}$; Agilent, Santa Clara, CA, USA) was used. Column oven temperature was set at $35^{\circ} \mathrm{C}$ and flow rate was $0.35 \mathrm{~mL} / \mathrm{min}$. The mobile phase consisted of $0.1 \%(\mathrm{v} / \mathrm{v})$ formic acid (A) and acetonitrile with $0.1 \%(v / v)$ formic acid (B). The QQQ 6430 triple quadrupole mass spectrometer and the Agilent MassHunter Workstation Software (Agilent, Santa Clara, CA, USA) were used for mass spectrometry. The positive and negative electrospray ionization (ESI) mode and dynamic multiple reaction monitoring (dMRM) mode were applied. Capillary voltage was $+4000 /-3500 \mathrm{~V}$, nitrogen drying temperature was $300^{\circ} \mathrm{C}$, flow rate was $11 \mathrm{~L} / \mathrm{h}$, and the pressure of the nebulizer was 40 psi. The total analytical time was $12.5 \mathrm{~min}$. The analytes were identified by comparing their retention times and mass spectra with the corresponding standards. For unavailable standards, the structural identification of phenolic compounds was done by comparing the mass fragment ions with the previously reported mass fragmentation patterns; and quantification was performed using the calibration curve of standards from the same phenolic group. The limits of detection (LOD) and quantification (LOQ) were determined at a signal-to-noise ratio of 3:1 and 10:1, respectively.

For the UPLC-MS/MS analysis, the frozen samples that were stored until analysis as described in the above section were slowly thawed at $+6^{\circ} \mathrm{C}$ on cooling pads until liquid again. Afterwards, they were centrifuged at $20,000 \times \mathrm{g}$ for $15 \mathrm{~min}$ at $4^{\circ} \mathrm{C}$. The supernatants $(200 \mu \mathrm{L}$ of the supernatant of the tissue homogenate) was then mixed with $10 \mu \mathrm{L}$ of a mixture of $\beta$-glucuronidase ( 250 units) and sulfatase (20 units), and then incubated at $37^{\circ} \mathrm{C}$ for $45 \mathrm{~min}$. The reaction mixture was extracted twice with ethyl acetate, to remove tissue debris of the homogenate. The combined ethyl acetate solutions were added to $10 \mu \mathrm{L}$ of a $20 \%$ ascorbic acid solution and evaporated to dryness in a vacuum centrifuge concentrator. Prior to the chromatographic analysis, the samples were reconstituted in $300 \mu \mathrm{L}$ of a $10 \%$ aqueous acetonitrile solu- 
tion $(v / v)$ and centrifuged at $6500 \times \mathrm{g}$ for $5 \mathrm{~min}$. The supernatant was transferred to an injection vial and then an aliquot of $2.5 \mu \mathrm{L}$ of the supernatant was injected onto the UPLC column [Ganguly et al., 2016; Gonzales et al., 2015].

The results of the UPLC-MS/MS analysis were presented as AUClast, and $\mathrm{C}_{\max }$ values. These were obtained from the curves of the phenolic content in the tissues versus the time (T, days) of blackthorn flower extract administration to mice as the area under the curve and the maximum concentration, respectively. To compute the mean AUClast, $\mathrm{C}_{\max }$, and $\mathrm{T}_{\max }$ values, a non-compartmental pharmacokinetic analysis was done using Phoenix WinNonlin 8.0. software (Certara, Princeton, NJ, USA)

\section{Statistical analysis}

Data of TBARS, FRAP, and ABTS assays; tissue content of antioxidative defense molecules; and the AUClast and $\mathrm{C}_{\max }$ values were presented as means and standard deviation. All data were compared for statistically significant differences $(\mathrm{p} \leq 0.05)$ by the t-test between the control group and the blackthorn flower extract-treated group within each individual tissue. The Kruskal-Wallis ANOVA was used for testing the statistically significant differences $(\mathrm{p} \leq 0.05)$ between days of treatment for antioxidative parameters. All statistical analyses were conducted in the SPSS version 17.0 software (IBM, Armonk, NY, USA).

\section{RESULTS AND DISCUSSION}

Lipid peroxidation, antioxidative properties, and the content of antioxidative defense molecules in the mice tissues after blackthorn flower extract administration

Compared to the control animals, the administration of blackthorn flower extract to mice significantly $(\mathrm{p} \leq 0.05)$ lowered the lipid peroxidation (content of TBARS) in tissues (Figure $1 \mathrm{~A}-\mathrm{C}$ ). The inhibited lipid peroxidation was observed in all three assessed organs (intestine, liver, and kidneys) after three weeks of administration. Since no in vivo results can be found in literature for blackthorn, the closest study resembling ours was that evidencing the similar lipid peroxidation reduction recorded with Aronia melanocarpa extract [Broncel et al., 2010].

The antioxidative capacity of the tissues (Figure 2 and 3 ) was measured as FRAP and $\mathrm{ABTS}^{\cdot+}$ scavenging activity. Each method specifically showed slightly different mechanisms of tissue antioxidative capacity. In the intestine and liver, the FRAP value of blackthorn flower extract-treated group was slightly but significantly $(\mathrm{p} \leq 0.05)$ higher compared to the control group on the $28^{\text {th }}$ day, while in the kidneys it did not differ statistically during the experiment. In turn, the antioxidant capacity determined as the ABTS •+ scavenging activity of the intestine was the highest $(\mathrm{p} \leq 0.05)$ already on the $7^{\text {th }}$ and $28^{\text {th }}$ day of the experiment. In the liver, FRAP was significantly higher in the exposed $(\mathrm{p} \leq 0.05)$ animals on the $28^{\text {th }}$ day only. In the kidneys, the antioxidative capacity measured as both FRAP and ABTS ${ }^{\cdot+}$ scavenging activity was not significantly different between the control and the blackthorn flower extract-treated animals. In general, it seems that at least four weeks of consumption is nec-
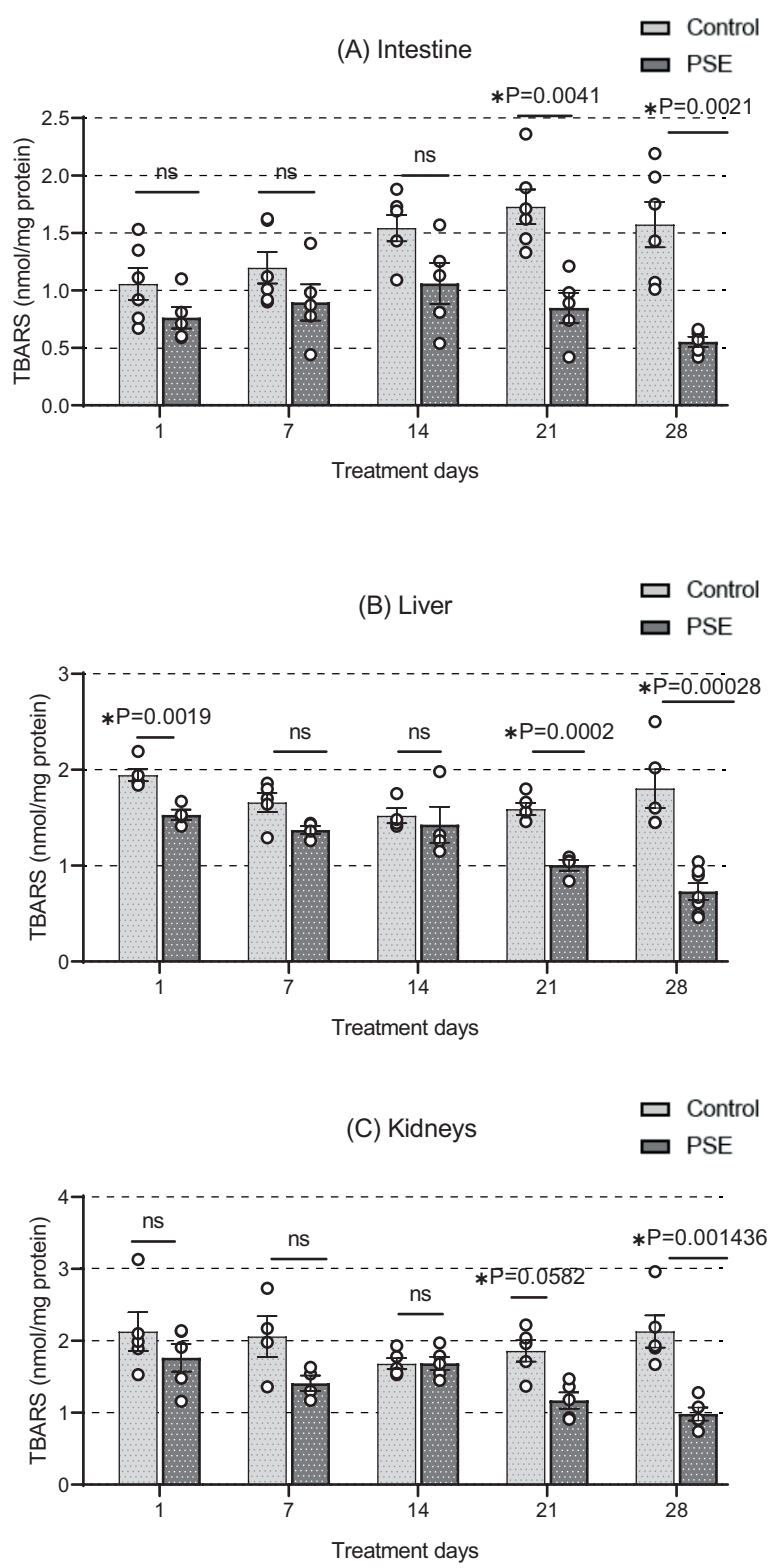

FIGURE 1. The lipid peroxidation expressed as the content of thiobarbituric acid reactive substances (TBARS) in the (A) intestine, (B) liver, and (C) kidneys; PSE - blackthorn flower extract-treated group. The values that are statistically different between control and PSE-treated group are marked with $\mathrm{p}$ value of t-test. ns - no statistically significant differences $(p>0.05)$.

essary to observe positive antioxidative effects in the intestine and liver using FRAP and/or $\mathrm{ABTS}^{\cdot+}$ method. Similar trends were found for other phenolic- and polyphenol-rich plants. For example, Nakhaee et al. [2009] and Salahshoor et al. [2019] showed an increased antioxidative potential (determined with the FRAP method) of liver tissue of streptozotocin-induced diabetic rats after dosing Eucalyptus globulus and Fucaria vulgaris, respectively.

In concordance with the pattern of described TBARS, FRAP, and $\mathrm{ABTS}^{\cdot+}$ scavenging activity changes, the SOD activity of intestine, liver, and kidneys (Table 1) showed somewhat different increase specific for each organ. The SOD activity of intestine and liver of the treated animals was significantly 
TABLE 1. The activity of superoxide dismutase (SOD) and catalase (CAT), and content of reduced glutathione (GSH) in the mice tissues after 1-28 days of daily repeated oral administration of the blackthorn flower extract (PSE) compared to these of untreated control mice.

\begin{tabular}{|c|c|c|c|c|c|c|}
\hline & \multicolumn{2}{|c|}{ Intestine } & \multicolumn{2}{|c|}{ Liver } & \multicolumn{2}{|c|}{ Kidneys } \\
\hline & Control & PSE & Control & PSE & Control & PSE \\
\hline \multicolumn{7}{|c|}{ SOD activity (U/mg proteins) } \\
\hline 1 day & $6.03 \pm 0.54^{b}$ & $8.17 \pm 1.63^{\mathrm{c}}$ & $14.26 \pm 1.87^{\mathrm{a}}$ & $10.43 \pm 3.08^{\mathrm{c}}$ & $10.83 \pm 3.53^{b}$ & $12.38 \pm 2.04^{b}$ \\
\hline 7 day & $9.06 \pm 1.23^{\mathrm{a}}$ & $6.68 \pm 0.46^{\mathrm{c}}$ & $11.42 \pm 4.97^{\mathrm{a}}$ & $12.4 \pm 0.84^{c}$ & $10.41 \pm 1.53^{b}$ & $12.51 \pm 1.93^{b}$ \\
\hline 14 day & $7.85 \pm 1.33^{\mathrm{b}}$ & $7.32 \pm 1.76^{\mathrm{c}}$ & $10.86 \pm 2.11^{\mathrm{a}}$ & $13.31 \pm 2.04^{c}$ & $16.97 \pm 1.54^{\mathrm{a}}$ & $21.38 \pm 1.17^{\mathrm{a}}$ \\
\hline 21 day & $5.55 \pm 2.42^{\mathrm{b}}$ & $10.39 \pm 1.00 \#^{\mathrm{b}}$ & $12.78 \pm 2.91^{\mathrm{a}}$ & $17.31 \pm 1.08 \#^{\mathrm{b}}$ & $11.18 \pm 1.94^{b}$ & $14.04 \pm 1.92^{\mathrm{b}}$ \\
\hline 28 day & $10.17 \pm 2.31^{\mathrm{a}}$ & $14.53 \pm 2.17 \#^{\mathrm{a}}$ & $15.44 \pm 1.49^{\mathrm{a}}$ & $22.93 \pm 3.21 \#^{\mathrm{a}}$ & $12.78 \pm 1.81^{\mathrm{b}}$ & $21.42 \pm 3.93 \#^{\mathrm{a}}$ \\
\hline \multicolumn{7}{|c|}{ CAT activity (U/mg proteins) } \\
\hline 1 day & $5.8 \pm 1.96^{\mathrm{b}}$ & $5.93 \pm 3.63^{b}$ & $115.11 \pm 12.17^{\mathrm{a}}$ & $100.51 \pm 20.19^{\mathrm{a}, \mathrm{b}}$ & $106.23 \pm 28.06^{\mathrm{a}}$ & $95.86 \pm 8.26^{\mathrm{a}}$ \\
\hline 7 day & $7.03 \pm 4.03^{\mathrm{a}}$ & $6.94 \pm 1.07^{\mathrm{d}, \mathrm{a}}$ & $75.44 \pm 11.62^{\mathrm{b}}$ & $92.06 \pm 5.28 \#^{\mathrm{b}}$ & $117.16 \pm 30.49^{a}$ & $91.26 \pm 9.46^{\mathrm{a}}$ \\
\hline 14 day & $6.12 \pm 3.64^{\mathrm{a}}$ & $11.1 \pm 1.07^{\mathrm{a}}$ & $66.95 \pm 19.21^{\mathrm{b}}$ & $80.61 \pm 13.76 \#^{\mathrm{b}}$ & $88.11 \pm 29.09^{a}$ & $98.28 \pm 39.31^{\mathrm{a}}$ \\
\hline 21 day & $7.47 \pm 3.81$ & $3.53 \pm 1.43^{b}$ & $50.9 \pm 15.29^{\mathrm{a}}$ & $70.36 \pm 21.53 \#^{\mathrm{b}}$ & $78.37 \pm 44.21^{\mathrm{a}}$ & $86.48 \pm 25.37^{\mathrm{a}}$ \\
\hline 28 day & $9.49 \pm 4.94^{\mathrm{a}}$ & $9.78 \pm 3.89^{\mathrm{a}}$ & $93.91 \pm 25.84^{\mathrm{a}}$ & $151.89 \pm 27.96 \#^{\mathrm{a}}$ & $61.13 \pm 19.76^{\mathrm{b}}$ & $83.42 \pm 24.72^{\mathrm{a}}$ \\
\hline \multicolumn{7}{|c|}{ GSH content ( $\mu \mathrm{M} / \mathrm{mg}$ proteins) } \\
\hline 1 day & $41.44 \pm 9.94^{\mathrm{b}}$ & $36.26 \pm 6.91^{\mathrm{c}}$ & $61.77 \pm 9.56^{\mathrm{b}}$ & $55.59 \pm 22.22^{b}$ & $38.61 \pm 14.34^{\mathrm{b}}$ & $36.87 \pm 5.47^{\mathrm{b}, \mathrm{c}}$ \\
\hline 7 day & $57.86 \pm 16.81^{\mathrm{a}}$ & $53.76 \pm 6.08^{\mathrm{b}}$ & $49.77 \pm 14.33^{\mathrm{b}}$ & $66.95 \pm 24.75^{\mathrm{b}}$ & $31.24 \pm 9.64^{\mathrm{b}}$ & $31.89 \pm 6.64^{c}$ \\
\hline 14 day & $52.73 \pm 12.39^{\mathrm{a}}$ & $36.78 \pm 4.22^{\mathrm{c}}$ & $50.79 \pm 12.52^{\mathrm{b}}$ & $71.65 \pm 22.66^{\mathrm{b}}$ & $33.19 \pm 7.63^{b}$ & $55.04 \pm 12.78 \#^{b}$ \\
\hline 21 day & $55.43 \pm 18.91^{\mathrm{a}}$ & $65.99 \pm 6.84^{\mathrm{b}}$ & $60.01 \pm 11.09^{b}$ & $79.13 \pm 15.71 \#^{\mathrm{b}}$ & $38.61 \pm 16.47^{\mathrm{b}}$ & $56.94 \pm 14.76^{\mathrm{b}}$ \\
\hline 28 day & $76.79 \pm 12.69^{a}$ & $114.12 \pm 9.94 \#^{\mathrm{a}}$ & $109.81 \pm 25.45^{\mathrm{a}}$ & $138.15 \pm 26.51 \mathrm{\#}^{\mathrm{a}}$ & $62.64 \pm 9.23^{\mathrm{a}}$ & $93.58 \pm 28.76 \# \mathrm{a}$ \\
\hline
\end{tabular}

\# The statistically significant differences $(\mathrm{p} \leq 0.05)$ between the control group and the PSE-treated group on the day of sampling (within rows). The different superscript letters (a-e) show statistically significant difference $(\mathrm{p} \leq 0.05)$ between the $1^{\text {st }}, 7^{\text {th }}, 14^{\text {th }}, 21^{\text {st }}, 28^{\text {th }}$ day of sampling within the control or the PSE group (within columns). The values are expressed as means \pm standard deviation (SD).

higher compared to that of control groups $(\mathrm{p} \leq 0.05)$ after three weeks of consumption (from $21^{\text {st }}$ until $28^{\text {th }}$ day). In the kidneys, a significant increase $(\mathrm{p} \leq 0.05)$ in SOD activity occurred later and was recorded only after four weeks of treatment. Since there is no previous data on in vivo antioxidative effects of $P$. spinosa flower extract, the results could be only compared to other plant species rich in polyphenols. For example, Nardi et al. [2016] investigated and compared the anti-inflammatory and antioxidative effects of goji berry, blueberry, and cranberry extracts administrated to mice. Mice were treated for 10 days with 50 and $200 \mathrm{mg}$ of extract per $\mathrm{kg} \mathrm{bw}$. The antioxidant status of liver was determined by testing GSH concentration and CAT activity. Both were the highest in the group that received goji berries extract and the lowest in the group that obtained the blueberries extract. Similarly, Jin \& Yin [2012] investigated the antioxidant effect of polyphenols from leaves of bamboo plants on the aging process of mice. Three groups of mice were treated with the leaf extract at doses of 20,40 , and $80 \mathrm{mg} / \mathrm{kg} \mathrm{bw}$. Their antioxidant status was measured by determining SOD, glutathione peroxidase (GSH-Px), and CAT activity, and total antioxidant capacity with the ORAC method. Compared with the control group, the activity of all enzymes in the serum and liver were statistically significantly higher in the groups treated with the leaf extract. In turn, phenolics from grapes and wine modulated SOD, GSH, and CAT levels in mice liver and kidneys [Landeka Jurčević et al., 2017]. Interestingly, the CAT activity (Table 1$)$ increased $(\mathrm{p} \leq 0.05)$ only in the liver as a result of blackthorn flower extract treatment, compared to the control animals. The onset of activation in the liver was very early in the experiment, i.e. from the $7^{\text {th }}$ day onwards. Intestine and kidneys did not show significantly different activity in the treated animals compared to their controls, respectively. The GSH contents (Table 1) in all tissues of blackthorn flower extract administered animals were higher compared to these of controls. They increased $(p \leq 0.05)$ by the end of the fourweek treatment (on the $28^{\text {th }}$ day). However, only in the liver such a significant increase $(p \leq 0.05)$ started earlier - on the $21^{\text {th }}$ day of the experiment (Table 1). In general, liver was the most prominent organ where induced activity of antioxidative defense molecules was recorded, while kidneys were the least responsive organ for the induction of tissue antioxidative markers.

\section{Does the blackthorn flower extract has antioxidant properties in mammalian organism?}

This important fundamental question addressed in this work was based on the previous publications that demonstrat- 
ed antioxidant and other bioactive properties of the blackthorn flower extract under in vitro conditions [Elez-Garofulić et al., 2018; Lovrić et al., 2017; Marchelak et al., 2017; Meschini et al., 2017; Mikulic-Petkovsek et al., 2016; Olszewska \& Wolbis, 2001; Pinacho et al., 2015]. The results presented in Figure 1 A-C and Table 1 indirectly show the reduction of oxidative stress that occurred in vivo in all major entry and excretory organs after ingestion and application of the blackthorn flower extract in mice, but mainly after three to four weeks of daily extract consumption.

The results also prove that the blackthorn flower extract has a similarly significant oxidation-inhibiting potential (Figure 2 and 3) as other plants that are rich sources of phenolics and were previously verified as good antioxidants. Similar properties as in our work are shown for other numerous plants, for example Aronia melanocarpa, for whom it was demonstrated that the 8-week consumption of its extract by animals lowered the serum MDA concentration in the experimental model of the metabolic syndrome [Broncel et al., 2010]. Those results obtained in mice were later confirmed in humans. For example, the consumption of Aronia melanocarpa juice prior to an ergonomic test in humans [Pilaczynska-Szczesniak et al., 2005], caused a significant reduction in DNA damage and reactive oxidative species (ROS) concentration and significant improvement of oxidative stress markers, antioxidant enzyme activity, and mitochondrial performance. Therefore, we expect the $P$. spinosa flower extract to be equally efficient in humans as tested in this model. Similar effects, noticed first in animals and then in humans, were recorded for many nutritional products and fruits such as tea, black wine, apple juice and goji berries, etc., plants which are known to contain large amounts of phenolics [Ganguly et al., 2016; Jin \& Yin, 2012; Landeka Jurčević et al., 2017; Nardi et al., 2016; Olszewska \& Wolbis, 2001; Teng \& Chen et al., 2019].

Definitely, based on the presented results, we can confirm that this major finding of antioxidative properties in vivo, supports the in vitro properties of antioxidant effects of blackthorn extract earlier reported by Marchelak et al. [2017] and other authors [Elez-Garofulić et al., 2018; Lovrić et al., 2017; Meschini et al., 2017; Mikulic-Petkovsek et al., 2016; Olszewska \& Wolbis, 2001; Pinacho et al., 2015]. However, the prolonged intake of at least three weeks is necessary to achieve first observable antioxidative bioactivity in healthy (not pathologically challenged) mice at the dose of $25 \mathrm{mg}$ of TP/kg bw. This result can serve as a guideline for future mechanistic studies in mice and based on estimations and literature it remains to be seen if a dose calculated to human equivalent dose (HED) would achieve a similar effect in humans.

\section{What are the mechanistic and molecular explanations of the observed antioxidative properties of a blackthorn flower extract in mice tissues which might bring innovation to this and similar future studies?}

We believe that the blackthorn flower extract in mice caused the boosting of beneficial physiological or antioxidant effects in the target tissues by molecular mechanism described previously [Bao et al., 2018; Dominko \& Đikić, 2018; Dominko et al., 2020; Squillaro et al., 2018]. Based on the literature, we
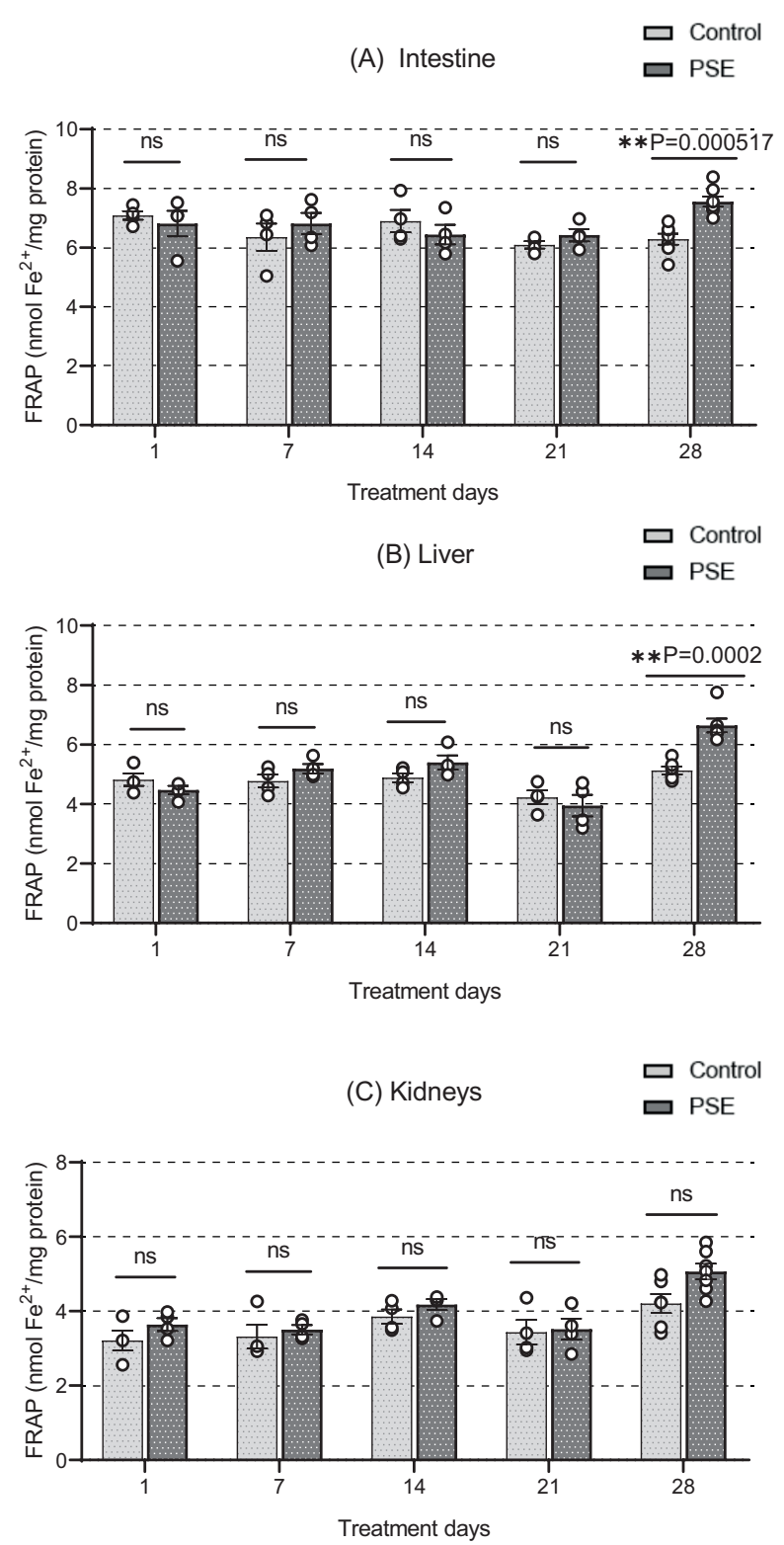

FIGURE 2. The antioxidant capacity of the tissue homogenates as ferric reducing antioxidant power (FRAP) of the (A) intestine, (B) liver, and (C) kidneys of mice treated with blackthorn flower extract and untreated control animals (Control). PSE - blackthorn flower extract-treated group. The values that are statistically different between control and PSE-treated group are marked with $\mathrm{p}$ value of t-test. ns - no statistically significant differences $(p>0.05)$.

provide two major mechanistic explanations and hypotheses that can explain the observed inhibition of lipid peroxidation and increased antioxidative activity in mice tissues after three to four weeks of consumption.

The first presumption and explanation is that the lowered lipid peroxidation (TBARS) is a consequence of the direct ROS scavenging properties of the bioabsorbed and bioavailable phenolics that were accumulated in the tissues (as listed for each tissue in Tables 2-4 and discussed in the next section). The second mechanistic explanation of the antioxidative effects could be that those phenolics all together synergistically indirectly induced the transcriptional mechanism (and other cellular mechanisms) for the production of in- 

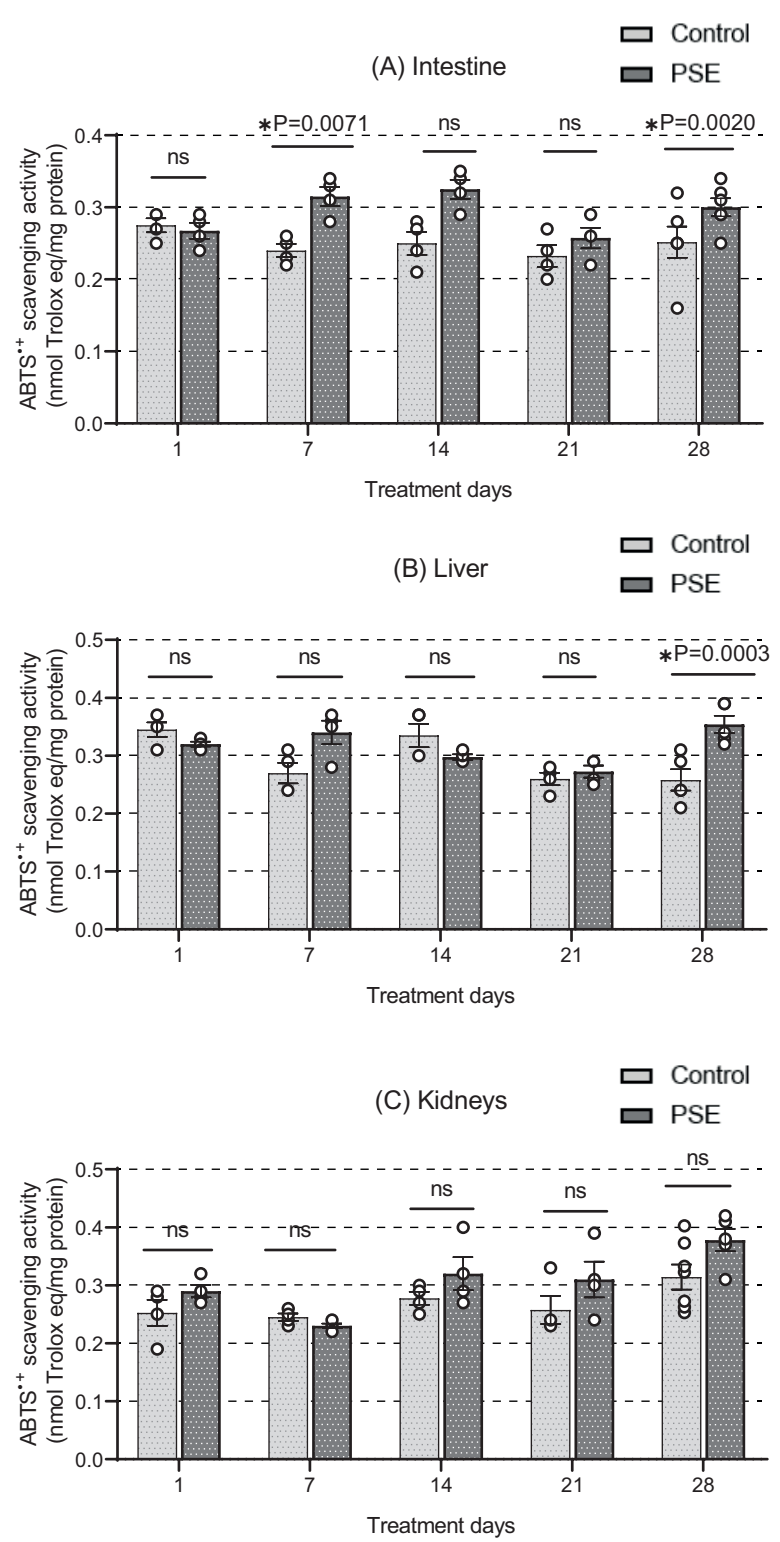

FIGURE 3. The ABTS ${ }^{\cdot+}$ scavenging activity of the tissue homogenates (A) intestine, (B) liver and, (C) kidneys of mice treated with blackthorn flower extract and untreated control animals (Control). PSE - blackthorn flower extract-treated group. The values that are statistically different between control and PSE-treated group are marked with $\mathrm{p}$ value of t-test ns - no statistically significant differences $(p>0.05)$.

ternal cellular antioxidative defense enzymes and molecules (CAT, GSH, SOD, and others). There is also a possibility that both proposed mechanisms took place in parallel, probably by the early onset (third week) of scavenging properties and later (fourth week) jointly supported by induction. In support of the first mechanical explanation of the direct scavenging activities by organ-bioavailable phenolics, we hypothesized that the phenolic compounds bioabsorbed in tissues would increase the overall antioxidant capacity of tissue homogenates. However, both FRAP and $\mathrm{ABTS}^{*+}$ scavenging activity method did not yield similar positive results for all tissues - an increase in the antioxidative capacity was recorded only in liver and/or intestine after the fourth week of extract consumption. These results could support the proposed hy- pothesis only to the limited extent. Perhaps, the use of other antioxidative tests would give positive results in the kidneys, as in the case of Jin \& Yin [2012] who investigated the antioxidant effect of phenolics from leaves of bamboo plants in mice tissues based on the oxygen radical absorbance capacity (ORAC). Thus, one important guideline for future studies on the similar model is to incorporate diverse antioxidative measurements in tissues.

The second explanation of the changes taking place in the tissues of mice after blackthorn flower extract administration may be the indirect effect of phenolics on cellular and molecular mechanisms and activation of SOD, GSH, or CAT cellular pathways of the antioxidative defense. Those antioxidative effects achieved by molecular mechanisms were described in the literature [Dominko \& Đikić, 2018; Dominko et al., 2020; Squillaro et al., 2018]. Phenolics boost the activation of transcription factors Erk-Nrf2-HO1, GCLM, and TrxR1 signal pathway and enhance the antioxidant enzymes such as heme oxygenase-1, phase II detoxification enzymes, and enzymes involved in GSH metabolism [Bao et al., 2018; Dominko \& Đikić, 2018; Dominko et al., 2020; Nardi et al., 2016; Squillaro et al., 2018]. Expressions of phase II detoxification and antioxidant enzyme genes are controlled by the antioxidant response element (ARE), which contains genes that are regulated by the nuclear factor erythroid 2-related factor 2 (Nrf2). Thus, after activation, $\mathrm{Nrf}-2$ dissociates from Keap 1 and is transferred into the nucleus to activate the translation of antioxidant genes and phase II detoxification genes, such as HO-1, NAD(P)H quinone oxidoreductase 1 (NQO1), and glutamate-cysteine ligase modifier (GCLM) [Dominko \& Đikić, 2018; Dominko et al., 2020]. Reduced glutathione $(\mathrm{GSH})$ can efficiently eliminate electrophiles and ROS that are generated during the chemical metabolism within cells. It is known that the enhancement of endogenous antioxidant defense by flavonoids is associated with the direct elimination of reactive oxygen species, inhibition of lipid peroxidation, reduction of oxidized glutathione level, increase of reduced glutathione level, and restoration of activities of antioxidant enzymes (superoxide dismutase, catalase, glutathione $S$-transferase, and glucose 6-phosphate dehydrogenase) [Dominko \& Đikić, 2018; Dominko et al., 2020]. Many studies have reported that herbal extracts modulate the expression of glutamate-cysteine ligase (GCL) which consists of catalytic (GCLC) and modifier (GCLM) subunits, which is a rate-limiting enzyme of GSH synthesis. The secondary mechanism could refer to the neutralization of oxidative species, and inhibition of the activation of the nuclear transcription factor- $\mathrm{KB}(\mathrm{NF}-\mathrm{\kappa B})$ signaling pathways [Bao et al., 2018; Nardi et al., 2016; Squillaro et al., 2018].

In this study, the activation of SOD, CAT, and GSH in the group receiving the blackthorn flower extract was tissue-specific. In all organs, there was an increased SOD activity but it occurred on different days of the experiment. Such an increase in kidneys was observed on the $28^{\text {th }}$ day but not earlier, whereas in the liver a slight (although still statistically not significant) increase was recorded already on the $14^{\text {th }}$ day of the experiment that became significant between $21^{\text {st }}-28^{\text {th }}$ day. Therefore, the accumulation of superoxide anion was a consequence of mitochondrial activity 
TABLE 2. Phenolic compound profile in the mice intestine after 28 days of daily oral administration of the blackthorn flower extract compared to untreated control group expressed as area under the curve of phenolic content in the tissue vs. treatment period (AUClast), maximal concentration $\left(\mathrm{C}_{\max }\right)$, and day of the experiment when it was achieved $\left(\mathrm{T}_{\max }\right)$.

\begin{tabular}{|c|c|c|c|c|}
\hline Phenolic compound & & AUClast $(\mathrm{h} \cdot \mu \mathrm{g} / \mathrm{g}) \#$ & $\mathrm{C}_{\max }(\mu \mathrm{g} / \mathrm{g}) \#$ & $\mathrm{~T}_{\max }$ (day) \\
\hline \multicolumn{5}{|c|}{ Phenolic acids } \\
\hline \multirow{2}{*}{ Caffeic acid } & Control & $41.6 \pm 17.4$ & $0.20 \pm 0.05$ & 7 \\
\hline & PSE & $111.8 \pm 13.9$ & $0.37 \pm 0.02$ & 7 \\
\hline \multirow{2}{*}{$p$-Coumaric acid } & Control & $186.7 \pm 37.4$ & $0.47 \pm 0.14$ & 21 \\
\hline & PSE & $444.9 \pm 6.3$ & $1.66 \pm 0.94$ & 1 \\
\hline \multirow{2}{*}{ 3-O-p-Coumaroylquinic acid } & Control & 1 & 1 & \\
\hline & PSE & $71.8 \pm 14.4$ & $0.19 \pm 0.02$ & 7 \\
\hline \multirow{2}{*}{ 4-O-p-Coumaroylquinic acid } & Control & $627.7 \pm 4.2$ & $1.22 \pm 0.05$ & 1 \\
\hline & PSE & $1095.0 \pm 27.8$ & $2.16 \pm 1.27$ & 21 \\
\hline \multirow{2}{*}{ Ferulic acid } & Control & $368.3 \pm 61.5$ & $1.03 \pm 0.36$ & 21 \\
\hline & PSE & $740.9 \pm 9.7$ & $1.68 \pm 0.95 \mathrm{~ns}$ & 1 \\
\hline \multirow{2}{*}{ 3-O-Feruloylquinic acid } & Control & $211.9 \pm 37.3$ & $0.62 \pm 0.13$ & 7 \\
\hline & PSE & $768.4 \pm 6.3$ & $4.60 \pm 0.42$ & 7 \\
\hline \multirow{2}{*}{ Gallic acid } & Control & $215.1 \pm 96.7$ & $1.27 \pm 0.67$ & 1 \\
\hline & PSE & $575.2 \pm 12.6$ & $2.20 \pm 1.27 \mathrm{~ns}$ & 7 \\
\hline \multicolumn{5}{|c|}{ Flavones } \\
\hline \multirow{2}{*}{ Luteolin } & Control & $89.5 \pm 19.2$ & $0.19 \pm 0.10$ & 7 \\
\hline & PSE & $171.8 \pm 30.6$ & $0.64 \pm 0.28 \mathrm{~ns}$ & 1 \\
\hline \multirow{2}{*}{ Apigenin } & Control & $188.3 \pm 17.8$ & $0.88 \pm 0.14$ & 1 \\
\hline & PSE & $523.9 \pm 72.5$ & $2.5 \pm 0.25$ & 1 \\
\hline \multicolumn{5}{|c|}{ Flavan-3-ols } \\
\hline \multirow{2}{*}{ (-)-Epigallocatechin 3-gallate } & Control & $6.3 \pm 0.8$ & $0.02 \pm 0.01$ & 21 \\
\hline & PSE & $14.5 \pm 3.9$ & $0.17 \pm 0.01$ & 28 \\
\hline \multicolumn{5}{|c|}{ Flavonols } \\
\hline \multirow{2}{*}{ Kaempferol 3-O-glucoside } & Control & $93.5 \pm 2.1$ & $0.16 \pm 0.00$ & 7 \\
\hline & PSE & $146.1 \pm 3.8$ & $0.29 \pm 0.17 \mathrm{~ns}$ & 7 \\
\hline \multirow{2}{*}{ Kaempferol pentoside } & Control & $1344.3 \pm 6.1$ & $2.74 \pm 0.01$ & 7 \\
\hline & PSE & $1559.4 \pm 74.7$ & $5.29 \pm 2.90 \mathrm{~ns}$ & 1 \\
\hline \multirow{2}{*}{ Kaempferol rhamnoside } & Control & 1 & 1 & \\
\hline & PSE & $9.9 \pm 0.01$ & $0.05 \pm 0.02$ & 28 \\
\hline \multirow{2}{*}{ Kaempferol pentosyl-hexoside } & Control & $260.6 \pm 13.9$ & $0.51 \pm 0.01$ & 7 \\
\hline & PSE & $329.4 \pm 10.2$ & $0.85 \pm 0.45$ & 1 \\
\hline \multirow{2}{*}{ Quercetin 3-O-glucoside } & Control & $63.9 \pm 10.2$ & $0.16 \pm 0.01$ & 7 \\
\hline & PSE & $151.0 \pm 12.5$ & $0.55 \pm 0.05$ & 21 \\
\hline \multirow{2}{*}{ Quercetin 3-O-rutinoside } & Control & $270.3 \pm 4.29$ & $0.77 \pm 0.01$ & 7 \\
\hline & PSE & $952.0 \pm 12.1$ & $1.73 \pm 0.21$ & 1 \\
\hline \multirow{2}{*}{ Quercetin acetyl-hexoside } & Control & $219.2 \pm 23.8$ & $0.51 \pm 0.01$ & 28 \\
\hline & PSE & $429.9 \pm 0.8$ & $0.67 \pm 39.00 \mathrm{~ns}$ & 28 \\
\hline \multirow{2}{*}{ Quercetin rhamnoside } & Control & $387.7 \pm 11.8$ & $0.95 \pm 0.10$ & 14 \\
\hline & PSE & $723.7 \pm 17.3$ & $1.67 \pm 0.94 \mathrm{~ns}$ & 1 \\
\hline
\end{tabular}

\#The statistically significant differences $(\mathrm{p} \leq 0.05)$ between the control group and the PSE-treated group for each individual phenolic compound were determined excluding values marked with ns - no statistically significant differences ( $p>0.05)$. PSE - blackthorn flower extract-treated group; / - not detected. AUClast - area under the curve, $\mathrm{C}_{\max }$ - maximal detected concentration, $\mathrm{T}_{\max }$ - day of experiment when maximal concentration was detected. 
TABLE 3. Phenolic compound profile in the mice liver after 28 days of daily oral administration of the blackthorn flower extract compared to untreated control group expressed as area under the curve of phenolic content in the tissue vs. treatment period (AUClast), maximal concentration $\left(\mathrm{C}_{\max }\right)$, and day of the experiment when it was achieved $\left(\mathrm{T}_{\max }\right)$.

\begin{tabular}{|c|c|c|c|c|}
\hline Phenolic compound & & AUClast $(\mathrm{h} \cdot \mu \mathrm{g} / \mathrm{g}) \#$ & $\mathrm{C}_{\max }(\mu \mathrm{g} / \mathrm{g}) \#$ & $\mathrm{~T}_{\max }$ (day) \\
\hline \multicolumn{5}{|c|}{ Phenolic acids } \\
\hline \multirow{2}{*}{ Caffeic acid } & Control & $54.5 \pm 0.2$ & $0.23 \pm 0.01$ & 21 \\
\hline & PSE & $479.4 \pm 39.1$ & $1.78 \pm 0.15$ & 21 \\
\hline \multirow{2}{*}{ p-Coumaric acid } & Control & / & l & \\
\hline & PSE & $38.4 \pm 0.1$ & $0.16 \pm 0.03$ & 7 \\
\hline \multirow{2}{*}{ 3-O-p-Coumaroylquinic acid } & Control & $8.3 \pm 0.7$ & $0.03 \pm 0.02$ & 1 \\
\hline & PSE & $68.5 \pm 0.1$ & $0.25 \pm 0.01$ & 7 \\
\hline \multirow{2}{*}{ 4-O-p-Coumaroylquinic acid } & Control & $317.5 \pm 2.8$ & $0.53 \pm 0.01$ & 1 \\
\hline & PSE & $798.1 \pm 0.1$ & $1.42 \pm 0.00$ & 21 \\
\hline \multirow{2}{*}{ Ferulic acid } & Control & $494.6 \pm 0.4$ & $0.77 \pm 0.02$ & 14 \\
\hline & PSE & $835.8 \pm 3.6$ & $1.64 \pm 0.02$ & 28 \\
\hline \multirow{2}{*}{ Gallic acid } & Control & $76.9 \pm 88.1$ & $0.58 \pm 0.04$ & 28 \\
\hline & PSE & $110.1 \pm 16.2$ & $1.31 \pm 0.19$ & 28 \\
\hline \multicolumn{5}{|c|}{ Flavones } \\
\hline \multirow{2}{*}{ Luteolin } & Control & $51.3 \pm 3.3$ & $0.18 \pm 0.01$ & 7 \\
\hline & PSE & $78.7 \pm 1.0$ & $0.33 \pm 0.02$ & 7 \\
\hline \multicolumn{5}{|c|}{ Flavonols } \\
\hline \multirow{2}{*}{ (-)-Epicatechin 3-gallate } & Control & $169.2 \pm 2.4$ & $0.70 \pm 0.05$ & 14 \\
\hline & PSE & $265.9 \pm 0.1$ & $1.40 \pm 0.01$ & 14 \\
\hline \multirow{2}{*}{ (-)-Epigallocatechin 3-gallate } & Control & $256.6 \pm 0.1$ & $0.87 \pm 0.00$ & 14 \\
\hline & PSE & $400.0 \pm 61.5$ & $1.06 \pm 0.25 \mathrm{~ns}$ & 7 \\
\hline \multicolumn{5}{|c|}{ Flavonols } \\
\hline \multirow{2}{*}{ Kaempferol 3-O-glucoside } & Control & $71.6 \pm 0.4$ & $0.15 \pm 0.01$ & 1 \\
\hline & PSE & $108.3 \pm 0.3$ & $0.25 \pm 0.01$ & 7 \\
\hline \multirow{2}{*}{ Kaempferol rhamnoside } & Control & $8.0 \pm 1.1$ & $0.02 \pm 0.04$ & 7 \\
\hline & PSE & $26.2 \pm 0.5$ & $0.12 \pm 0.02$ & 7 \\
\hline \multirow{2}{*}{ Kaempferol acetyl-hexoside } & Control & $4.1 \pm 0.8$ & $0.02 \pm 0.05$ & 7 \\
\hline & PSE & $13.4 \pm 0.1$ & $0.07 \pm 0.01 \mathrm{~ns}$ & 7 \\
\hline \multirow{2}{*}{ Quercetin 3-O-glucoside } & Control & $70.6 \pm 0.8$ & $0.14 \pm 0.09$ & 7 \\
\hline & PSE & $168.6 \pm 0.1$ & $0.39 \pm 0.03$ & 1 \\
\hline \multirow{2}{*}{ Quercetin 3- $O$-rutinoside } & Control & $715.1 \pm 78.9$ & $1.55 \pm 0.03$ & 14 \\
\hline & PSE & $1113.1 \pm 0.6$ & $2.57 \pm 0.03$ & 14 \\
\hline \multirow{2}{*}{ Quercetin pentoside } & Control & $84.2 \pm 1.1$ & $0.13 \pm 0.01$ & 7 \\
\hline & PSE & $670.0 \pm 1.6$ & $1.44 \pm 0.02$ & 7 \\
\hline
\end{tabular}

\# The statistically significant differences $(\mathrm{p} \leq 0.05)$ between the control group and the PSE-treated group for each individual phenolic compound were determined excluding values marked with ns - no statistically significant differences $(p>0.05)$. PSE- blackthorn flower extract-treated group; / - not detected. AUClast - area under the curve, $\mathrm{C}_{\max }-$ maximal detected concentration, $\mathrm{T}_{\max }-$ day of experiment when maximal concentration was detected.

and boosted metabolism. For example, the liver was the only organ that from the earlier onset of experiment ( $7^{\text {th }}$ day) had increased CAT activity and the only organ whose catalase antioxidative pathway was induced. Other organs did not show CAT activation due to the blackthorn flower extract treatment. The liver was the only organ with increases in the values of all three parameters and the only organ that had increased CAT activity within the time of extract administration (but only on the $28^{\text {th }}$ day). Liver, opposite to other organs, has normally higher physiological expression of catalase, and is the organ with a high metabolic rate (biotransformation activity). Therefore, we are firmly convinced that, 
TABLE 4. Phenolic compound profile in the mice kidneys after 28 days of daily oral administration of the blackthorn flower extract compared to untreated control group expressed as area under the curve of phenolic content in the tissue $v s$. treatment period (AUClast), maximal concentration $\left(\mathrm{C}_{\max }\right)$, and day of the experiment when it was achieved $\left(\mathrm{T}_{\max }\right)$.

\begin{tabular}{|c|c|c|c|c|}
\hline Phenolic compound & & AUClast $(\mathrm{h} \cdot \mu \mathrm{g} / \mathrm{g}) \#$ & $\mathrm{C}_{\max }(\mu \mathrm{g} / \mathrm{g}) \#$ & $\mathrm{~T}_{\max }$ (day) \\
\hline \multicolumn{5}{|c|}{ Phenolic acids } \\
\hline \multirow{2}{*}{ 4-O-p-Coumaroylquinic acid } & Control & $412.3 \pm 11.1$ & $0.64 \pm 0.01$ & 28 \\
\hline & PSE & $1143.1 \pm 2.6$ & $2.06 \pm 0.04$ & 28 \\
\hline \multirow{2}{*}{ Ferulic acid } & Control & $261.6 \pm 2.8$ & $0.84 \pm 0.56$ & 21 \\
\hline & PSE & $1354.5 \pm 0.3$ & $5.45 \pm 0.00$ & 21 \\
\hline \multicolumn{5}{|c|}{ Flavones } \\
\hline \multirow{2}{*}{ Luteolin } & Control & $11.3 \pm 3.5$ & $0.13 \pm 0.15$ & 28 \\
\hline & PSE & $131.2 \pm 13.7$ & $0.52 \pm 0.19$ & 1 \\
\hline \multirow{2}{*}{ Apigenin } & Control & $128.2 \pm 1.0$ & $0.45 \pm 0.01$ & 1 \\
\hline & PSE & $349.2 \pm 2.6$ & $0.96 \pm 0.02$ & 21 \\
\hline \multicolumn{5}{|c|}{ Flavan-3-ols } \\
\hline \multirow{2}{*}{$(+)$-Catechin } & Control & $92.9 \pm 0.1$ & $0.21 \pm 0.00$ & 1 \\
\hline & PSE & $776.2 \pm 1.4$ & $1.41 \pm 0.01$ & 7 \\
\hline \multirow{2}{*}{ (-)-Epicatechin } & Control & $0.3 \pm 0.0$ & $0.02 \pm 0.03$ & 1 \\
\hline & PSE & $848.4 \pm 0.4$ & $1.55 \pm 0.00$ & 7 \\
\hline \multicolumn{5}{|c|}{ Flavonols } \\
\hline \multirow{2}{*}{ Quercetin 3-O-glucoside } & Control & $85.1 \pm 1.0$ & $0.15 \pm 0.00$ & 7 \\
\hline & PSE & $121.0 \pm 0.6$ & $0.19 \pm 0.00 \mathrm{~ns}$ & 1 \\
\hline \multirow{2}{*}{ Quercetin 3- $O$-rutinoside } & Control & $240.1 \pm 1.0$ & $0.64 \pm 0.35$ & 7 \\
\hline & PSE & $1764.0 \pm 6.7$ & $2.96 \pm 0.02$ & 14 \\
\hline \multirow{2}{*}{ Quercetin pentosyl-hexoside } & Control & $86.8 \pm 1.2$ & $0.13 \pm 0.00$ & 1 \\
\hline & PSE & $193.2 \pm 1.10$ & $0.40 \pm 0.00$ & 1 \\
\hline
\end{tabular}

\# The statistically significant differences $(\mathrm{p} \leq 0.05)$ between the control group and the PSE-treated group for each individual phenolic compound were determined excluding values marked with ns - no statistically significant differences ( $\mathrm{p}>0.05$ ). PSE - blackthorn flower extract-treated group; / - not detected AUClast - area under the curve, $\mathrm{C}_{\max }$ - maximal detected concentration, $\mathrm{T}_{\max }$ - day of experiment when maximal concentration was detected.

physiologically, it is possible that after 28 days of continuous intake of xenobiotic molecules in a higher concentration, peroxides were accumulating in hepatocytes and the expression and activity of catalase was increased. The GSH content also increased in all organs predominantly on the $28^{\text {th }}$ day. This significant change, although minor compared to the control animals, indicates that phenolics present in organs probably enhance the metabolic activity. Presumably, the metabolic processes of conjugation activated the elimination of xenobiotic molecules (phenolics) as normal physiological characteristics, since kidneys are the major organs where conjugated glutathione-xenobiotic complexes (in this case polyphenol residue conjugates) enter the excretory pathway, cleaved as mercapturic acids [Dominko \& Đikić, 2018]. The present study results are consistent with literature data, for example with Nardi et al. [2016] who investigated and compared the anti-inflammatory and antioxidative effects of goji berry, blueberry, and cranberry extracts in mice. Mice were treated with the extract at 50 and $200 \mathrm{mg} /$ $\mathrm{kg}$ bw for 10 days. The antioxidant activity was determined by testing the GSH content and CAT activity, which were the highest in the group that received goji berries extract and the lowest in the group that obtained the blueberries extract. Similarly, Jin \& Yin [2012] investigated the antioxidant effect of phenolics from leaves of bamboo plants on the aging process of mice. Three groups of mice were treated with the leaf extract at doses of 20,40 , and $80 \mathrm{mg} /$ $\mathrm{kg}$ bw. The authors reported that the CAT and SOD activity and the GSH content in the serum and liver decreased while the MDA levels increased significantly in the groups treated with the leaf extract, compared with the control group.

\section{Content of phenolic compounds in individual tissue following four-week administration of blackthorn flower extract in mice}

The selective and specific tissue content was observed for specific subgroups of phenolic compounds after the intake of the blackthorn flower extract (Tables 2-4). In the intestine 
INTESTINE

Feruloylquinic acid

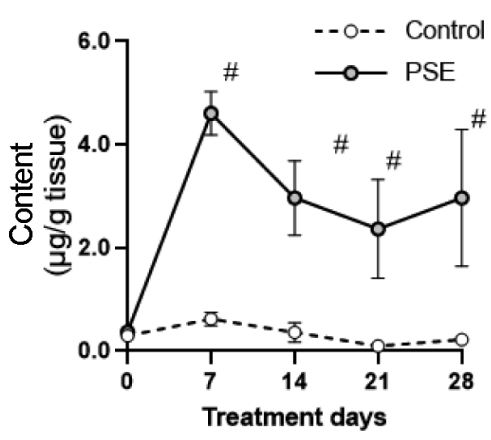

INTESTINE

Quercetin rhamnoside

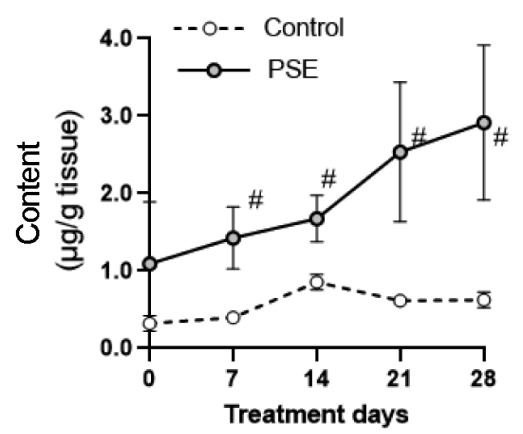

LIVER

Ferullic acid

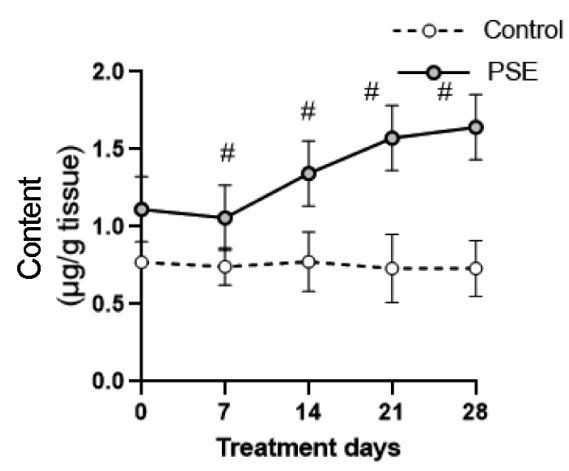

LIVER

Quercetin 3-O-rutinoside (Rutin)

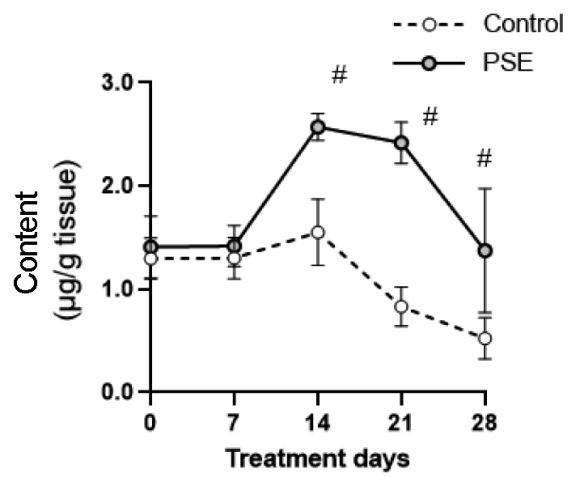

KIDNEYS

Ferullic acid

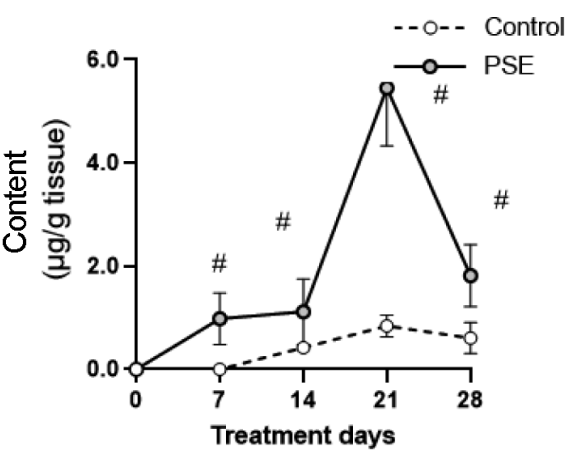

KIDNEYS

Quercetin 3-O-rutinoside (Rutin)

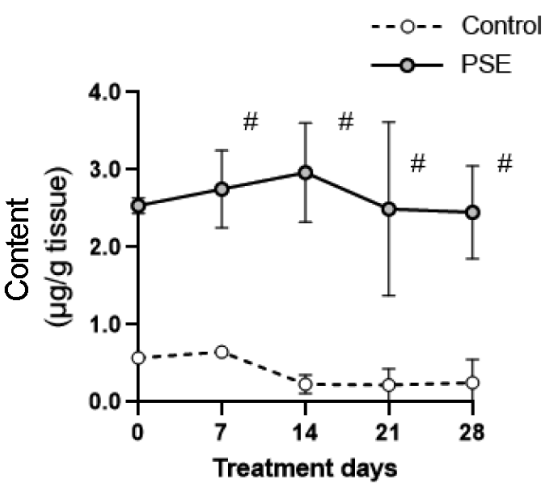

FIGURE 4. Individual phenolic content in the intestine, liver, and kidneys of mice treated with blackthorn flower extract and untreated control animals (control). PSE - blackthorn flower extract-treated group. \#The values are statistically different $(\mathrm{p} \leq 0.05)$ between untreated control and PSE-treated groups.

and the liver, more phenolics were detected than in the kidneys and their composition was generally similar.

Among the seven phenolic acids detected in the intestine, 3-O-feruloylquinic acid was the only one absent in the liver. Opposite to those tissues, only two phenolic acids, namely 4-O-p-coumaroylquinic acid and ferulic acid, were determined in the kidneys. Ferulic acid was, therefore, the only one present in all three organs and its AUClast after 28 days was the highest in the kidneys of the treated animals.

Among the flavan-3-ols, (+)-catechin and (-)-epicatechin were found only in the kidneys. (-)-Epicatechin 3-gallate was present only in the liver and (-)-epigallocatechin 3-gallate was detected in the intestine and liver. Among the flavonols, the intestine contained four kaempferol glycosides, while three and four quercetin glycosides were present in the liver and intestine, respectively. The least varied phenolic composition was observed in the kidneys, with no detected kaempferol glycosides and only three quercetin glycosides. Interestingly, quercetin 3-O-glucoside and quercetin 3-O-rutinoside were present in all three organs.

The specific distribution of phenolic compounds in each tissue was observed (Tables 2-4) Namely, in the intestine, 3-O-feruloylquinic acid was present with most prominently different $\mathrm{C}_{\max }$ that was approximately 4 times higher in the tissue of the treated animals than in the control ones. Intestine contained also other compounds in high quantities (either AUClast or $\mathrm{C}_{\max }$ ), such as 4-O-p-coumaroylqiunic acid, kaempferol pentoside, quercetin rhamnoside, and quercetin 3-O-rutinoside, but their difference from the control was less prominent than in 3-O-feruloylquinic acid (Table 2, Figure 4). In the liver, the highest AUClast values were determined for quercetin 3-O-rutinoside $(1113.1 \mathrm{~h} \cdot \mu \mathrm{g} / \mathrm{g})$ followed by ferulic acid $(835.8 \mathrm{~h} \cdot \mu \mathrm{g} / \mathrm{g})$ (Table 3, Figure 4). The content of phenolics in kidneys was generally lower. The highest $\mathrm{C}_{\max }$ was determined for ferulic acid and quercetin 3-O-rutinoside followed by 4-O-p-coumaroylquinic acid (Table 4, Figure 4).

\section{Does the distribution of phenolics occur in tissues after 28-day consumption of blackthorn flower extract?}

We further hypothesized that the differences in the antioxidative defense activation and specific organ patterns were a consequence of differences in the bioaccumulation of various phenolic compounds from the extract. Therefore, we decided to screen major phenolics in the analyzed organs (Tables 2-4, Figure 4). Probably, they were jointly and synergistically responsible for the observed antioxidative effects 
and no individual compound among detected ones could be, with certainty, proclaimed to individually cause the bioactive effects measured in each analyzed organ.

The selective tissue content and distribution was observed for specific subgroups of phenolic compounds of the blackthorn flower extract. Since mouse has a faster metabolism, in humans the time at which similar concentrations can be reached could probably be longer. However, current scientific methodology does not have the means to estimate concentrations of absorbed phenolics in human tissues in a similar manner of time dynamics as shown here in the animal model.

The lowest number of phenolics with a low concentration was observed in the kidneys. It was probably not only a consequence of lesser vascularization (than in the intestine and liver) or low absorption, but also a consequence of the enhanced polyphenol excretion and their removal with urine. Thus, we believe that the measured antioxidative effects and activation of SOD, CAT, or GSH, probably followed the specific phenolic bioacummulation pattern in each organ. In vivo research has shown that phenolic compounds are absorbed in larger amounts than previously thought and especially after long-term consumption they are able to increase plasma antioxidant capacity [Teng \& Chen, 2019]. Our study supports this observation. This effect was also noticed for many nutritional products such as tea, black wine and apple juice, which are known to contain large amounts of phenolics [Teng \& Chen, 2019]. However, the bioabsorption and organ distribution of only a small number of phenolics is well known, as described in, e.g., historic works on quercetin [Olthof et al., 2000; Wang et al., 2016]. In our previous publication, Đikić et al. [2018], in the same model but with the single acute dose (analyzed in different times within $24 \mathrm{~h}$ ), we have concluded that the serum does not give a true picture of phenolics content and distribution in body. Similar conclusions can be found in literature [Gonzales et al., 2015]. The number of compounds and their bioavailable concentrations were very low in the acute $(2 \mathrm{~h})$ experiment compared to this experiment here with 28 days of exposure, and the recorded antioxidant bioactivity in tissue confirming that the molecular bioabsorption actually happened. The exact analysis of tissues showed that the concentrations up to approximately $5 \mu \mathrm{g} / \mathrm{g}$ in the intestine were approximately 2-fold higher $v s$. concentrations in the liver, but liver and intestine shared a similar pattern of compound types distribution. This balance is probably the reflection of normal physiological enterohepatic recirculation. The phenolic contents in the kidneys were detected by UPLC-MS/MS in the experiment of Ganguly et al. [2016] following oral administration of black tea as the aqueous infusion and alcoholic extract to guinea pigs for 14 days. The authors reported the contents of (-)-epigallocatechin (49.1 and $34.2 \mathrm{ng} / \mathrm{g}$ tissue, respectively), (-)-epicatechin (47.8 and $22.3 \mathrm{ng} / \mathrm{g}$ tissue), (-)-epigallocatechin 3-gallate (91.8 and $45.0 \mathrm{ng} / \mathrm{g}$ tissue), and (-)-epicatechin 3 -gallate ( 22.5 and $12.8 \mathrm{ng} / \mathrm{g}$ tissue, respectively). If the content of flavan 3-ols in mice kidneys determined in our study was expressed in $\mathrm{ng} / \mathrm{g}$ tissue, the range would be between 210-1553 ng/g tissue, depending on the compound.
The higher values are probably due to the difference in experimental animals used (guinea pig $v s$. mice in this study) but also a longer (2 times) dosing regime in this study. The model used in this study shows that the consumption could be within line with safety standards for the concentration of bioabsobred phenolics from food supplements and medicinal plants [Harwood et al., 2007; Peng et al., 2016] and it the first published work on the antioxidative activity of blackthorn in vivo. Aside from fundamental knowledge of particular phenolics bioaccumulation and bioavailability and correlation to antioxidative effects, there is a practical value of the study in the way that the aqueous infusion in the form of an alcoholic extract can be used for production and consumption.

\section{CONCLUSION}

The contents of phenolics increased significantly in mice tissues after at least three weeks of blackthorn flower extract consumption. The extract had significant bioactive properties in vivo and induced antioxidative defense pathways in the organ-specific manner. Thus, the study demonstrates that the administration of Prunus spinosa flower extract to mice partially inhibited the oxidative stress in tissues. Among individual phenolic compounds of the extract, the study screened these bioavailable and absorbed. In the intestine, it was mainly 3-O-feruloylquinic acid, 4-O-p-coumaroylqiunic acid, kaempherol pentoside, and quercetin rhamnoside, in the liver - ferulic acid and quercetin 3-O-rutinoside, and in the kidneys - quercetin 3-O-rutinoside, ferulic acid, and 4-O-p-coumaroylquinic acid. Possibly, these phenolics in mixtures but together with other that were in lower contents, were responsible for the antioxidant effects of the blackthorn flower extract. It must be emphasized that, to the best of our knowledge, this is the first study on the antioxidative activity of blackthorn in vivo and there are no studies on human consumption conducted with the blackthorn flower extract.

\section{ACKNOWLEDGEMENTS}

We are grateful to the staff of the Animal Breeding Facility of the Department of Animal Physiology Faculty of Science, University of Zagreb, for their help during conduction of the in vivo experiment and to Dr. Zoran Zoric and Dr. Sandra Pedisic for their great effort during the preparation of UPLC-MS/MS data and results.

\section{RESEARCH FUNDING}

This work was supported by the project "Bioactive molecules of medical plants as natural antioxidants, microbicides, and preservatives" (KK.01.1.1.04.0093), co-financed by the Croatian Government and the European Union through the European Regional Development Fund-Operational Programme Competitiveness and Cohesion (KK.01.1.1.04.).

\section{CONFLICT OF INTEREST}

The authors declare no potential conflicts of interests. 


\section{ORCID IDs}

V. Balta https://orcid.org/0000-0002-0424-1173

D. Đikić https://orcid.org/0000-0003-0909-3488

I. Crnić https://orcid.org/0000-0002-7014-1103

D. Odeh https://orcid.org/0000-0002-6182-755X

N. Oršolić https://orcid.org/0000-0001-5102-3606

I. Kmetić https://orcid.org/0000-0001-5412-7128

T. Murati https://orcid.org/0000-0001-7157-400X

V. Dragović Uzelac https://orcid.org/0000-0002-4179-3727

I. Landeka Jurčević https://orcid.org/0000-0002-3785-1752

\section{REFERENCES}

1. Aebi, H. (1984). Catalase in vitro. Methods in Enzymology, 105, 121-126.

https://doi.org/10.1016/S0076-6879(84)05016-3

2. Alarcón, R., Pardo-de-Santayana, M., Priestley, C., Morales, R., Heinrich, M. (2015). Medicinal and local food plants in the south of Alava (Basque Country, Spain). Journal of Ethnopharmacology, 176, 207-224.

https://doi.org/10.1016/j.jep.2015.10.022

3. Bao, Y., Qu, Y., Li, J., Li, Y., Ren, X., Maffucci, K.G., Li, R. Wang, Z., Zeng, R. (2018). In vitro and in vivo antioxidant activities of the flowers and leaves from Paeonia rockii and identification of their antioxidant constituents by UHPLC-ESI-HRMSn via pre-column DPPH ${ }^{\bullet}$ reaction. Molecules, 23(2), art. no. 392. https://doi.org/10.3390/molecules23020392

4. Benzie, I.F., Strain, J.J. (1996). The ferric reducing ability of plasma (FRAP) as a measure of "antioxidant power": the FRAP assay. Analytical Biochemistry, 239(1),70-76. https://doi.org/10.1006/abio.1996.0292

5. Bioethic approval of the experimental procedure within the project, (2014). Document No. 251-58-10617-14-37, Faculty of Science, University of Zagreb, Croatia (in Croatian).

6. Broncel, M., Kozirog, M., Duchnowicz, P., Koter-Michalak, M., Sikora, J., Chojnowska-Jezierska, J. (2010). Aronia melanocarpa extract reduces blood pressure, serum endothelin, lipid, and oxidative stress marker levels in patients with metabolic syndrome. Medical Science Monitor, 16(1), 28-34.

7. Đikić, D., Balta, V., Kmetić, I., Murati, T., Orsolić, N., Dragovic Uzelac, V., Landeka Jurčević, I. (2018). UPLC/MS analysis of plasma bioavailability of 32 polyphenols in C57BL/6 mice treated with single acute dose (24 h) of flower extract of the blackthorn Prunus spinosa L. Molecular and Experimental Biology in Medicine, 2, 23-31.

8. Dominko, K., Đikić, D. (2018). Glutathionylation: a regulatory role of glutathione in physiological processes. Arhiv za Higijenu Rada i Toksikologiju, 69(1), 1-24. https://doi.org/10.2478/aint-2018-69-2966

9. Dominko, K., Đikić, D., Hecimovic, S. (2020). Enhanced activity of superoxide dismutase is a common response to dietary and genetically induced increased cholesterol levels. Nutritional Neuroscience, 23(5), 398-410. https://doi.org/10.1080/1028415X.2018.1511027

10. Elez-Garofulić, I., Zorić, Z., Pedisić, S., Brnčić, M., DragovićUzelac, V. (2018). UPLC-MS2 Profiling of blackthorn flower polyphenols isolated by ultrasound-assisted extraction. Journal of Food Science, 83(11), 2782-2789.

https://doi.org/10.1111/1750-3841.14368
11. Flohé, L., Ötting, F. (1984). Superoxide dismutase assays. Methods in Enzymology, 105, 93-104.

https://doi.org/10.1016/S0076-6879(84)05013-8

12. Ganguly, S.G., Mantha, S., Panda, K. (2016). Simultaneous determination of black tea-derived catechins and theaflavins in tissues of tea consuming animals using Ultra-Performance Liquid-Chromatography Tandem Mass Spectrometry. PLoS One, 11 (10), art. no. e0163498.

https://doi.org/10.1371/journal. pone.0163498

13. Gonzales, G.B., Smagghe, G., Grootaert, C., Zotti, M., Raes, K., Van Camp, J. (2015). Flavonoid interactions during digestion, absorption, distribution and metabolism: a sequential structure-activity/property relationship-based approach in the study of bioavailability and bioactivity. Drug Metabolism Reviews, 47(2), 175-90. https://doi.org/10.3109/03602532.2014.1003649

14. Guide for the Care and Use of Laboratory Animals (2011). Washington DC, USA, National Academies Press. 2011, 86-123.

15. Harwood, M., Danielewska-Nikiel, B., Borzelleca, J.F., Flamm, G.W., Williams, G.M., Lines, T.C.A. (2007). Critical review of the data related to the safety of quercetin and lack of evidence of in vivo toxicity, including lack of genotoxic/carcinogenic properties. Food and Chemical Toxicology, 45(11), 2179-2205.

https://doi.org.10.1016/j.fct.2007.05.015

16. Jin, S.L., Yin, Y.G. (2012). In vivo antioxidant activity of total flavonoids from indocalamus leaves in aging mice caused by D-galactose. Food and Chemical Toxicology, 50(10), 3814-3818. https://doi.org/10.1016/j.fct.2012.07.046

17. Katalinic, V., Modun, D., Music, I., Boban, M. (2005). Gender differences in antioxidant capacity of rat tissues determined by 2,2'-azinobis (3-ethylbenzothiazoline 6-sulfonate; ABTS) and ferric reducing antioxidant power (FRAP) assays. Comparative Biochemistry and Physiology C. Toxicology \& Pharmacology, 140(1), 47-52.

https://doi.org/10.1016/j.cca.2005.01.005

18. Kelly, E., Vyas, P., Weber, J.T. (2017). Biochemical properties and neuroprotective effects of compounds in various species of berries. Molecules, 23(1), art. no. 26. https://doi.org/10.3390/molecules23010026

19. Landeka Jurčević, I., Dora, M., Guberović, I., Petras, M., Rimac Brnčić, S., Đikić, D. (2017). Polyphenols from wine lees as a novel functional bioactive compound in the protection against oxidative stress and hyperlipidaemia. Food Technology and Biotechnology, 55(1), 109-116.

https://doi.org/10.17113/ftb.55.01.17.4894

20. Lovrić, V., Putnik, P., Kovačević, D.B., Jukić, M., Dragović-Uzelac, V. (2017). Effect of microwave-assisted extraction on the phenolic compounds and antioxidant capacity of blackthorn flowers. Food Technology and Biotechnology, 55(2), 243-250. https://doi.org/10.17113/ftb.55.02.17.4687

21. Lowry, D.H., Rosebrough, N.J., Farr, A.L. (1951). Protein measurement with the Folin-phenol reagent. The Journal of Biological Chemistry, 193(1), 265-275.

22. Marchelak, A., Owczarek, A., Matczak, M., Pawlak, A., Kolodziejczyk-Czepas, J., Nowak, P., Olszewska, M.A. (2017). Bioactivity potential of Prunus spinosa L. flower extracts: phytochemical profiling, cellular safety, pro-inflammatory enzymes inhibition and protective effects against oxidative stress in vitro. Frontiers in Pharmacology, 8, art. no. 680. https://doi.org/10.3389/fphar.2017.00680 
23. Menendez-Baceta, G., Aceituno-Mata, L., Tardío, J., Reyes-García, V., Pardo de Santayana, M. (2012). Wild edible plants traditionally gathered in Gorbeialdea (Biscay, Basque Country). Genetic Resources and Crop Evolution, 59(7), 1329-1347. https://doi.org/10.1007/s10722-011-9760-z

24. Meschini, S., Pellegrini, E., Condello, M., Occhionero, G., Delfine, S., Condello, G., Mastrodonato, F. (2017). Cytotoxic and apoptotic activities of Prunus spinosa Trigno ecotype extract on human cancer cells. Molecules, 22(9), art. no. 1578. https://doi.org/10.3390/molecules22091578

25. Mikulic-Petkovsek, M., Stampar, F., Veberic, R., Sircelj, H. (2016). Wild Prunus fruit species as a rich source of bioactive compounds. Journal of Food Science, 81 (8), C1928-C1937. https://doi.org/10.1111/1750-3841.13398

26. Murati, T., Miletić, M., Kolarić, J., Lovrić, V., Kovačević, D.B., Putnik, P., Jurčević, I.L., Đikić, D., Dragović-Uzelac, V., Kmetič, I. (2019). Toxic activity of Prunus spinosa L. flower extract in hepatocarcinoma cells. Arhiv za higijenu rada i toksikologiju, 70(4), 303-309.

https://doi.org/10.2478/aiht-2019-70-3322

27. Nakhaee, A., Bokaeian, M., Saravani, M., Farhangi, A., Akbarzadeh, A. (2009). Attenuation of oxidative stress in streptozotocin-induced diabetic rats by Eucalyptus globulus. Indian Journal of Clinical Biochemistry, 24(4), 419-425. https://doi.org/10.1007/s12291-009-0075-1

28. Nardi, G.M., Farias Januario, A.G., Freire, C.G., Megiolaro, F., Schneider, K., Perazzoli, M.R., Do Nascimento, S.R., Gon, A.C., Mariano, L.N., Wagner, G., Niero, R., Locatelli, C. (2016). Antiinflammatory activity of berry fruits in mice model of inflammation is based on oxidative stress modulation. Pharmacognosy Research, 8(1), 42-49. https://doi.org/10.4103/0974-8490.178642

29. NN 55/2013. Act on Animal Welfare, Croatia (2013). Official Gazette of the Republic of Croatia, 1129 (in Croatian).

30. Ohkawa, H., Ohishi, N., Yagi, K. (1979). Assay for lipid peroxides in animal tissues by thiobarbituric acid reaction. Analytical Biochemistry, 95(2), 351-358.

https://doi.org/10.1016/0003-2697(79)90738-3

31. Olszewska, M., Głowacki, R., Wolbís, M., Bald, E. (2001). Quantitative determination of flavonoids in the flowers and leaves of Prunus spinosa L. Acta Poloniae Pharmaceutical, 58(3), 199-203. https://europepmc.org/article/med/11712737.

32. Olszewska, M., Wolbiś, M. (2001). Flavonoids from the flowers of Prunus spinosa L. Acta Poloniae Pharmaceutical, 58(5), 367-372.

33. Olszewska, M., Wolbiś, M. (2002). Further flavonoids from the flowers of Prunus spinosa L. Acta Poloniae Pharmaceutical, 59(2), 133-137. https://europepmc.org/article/med/12365605

34. Olthof, M.R., Hollman, P.C., Vree, T.B., Katan, M.B. (2000) Bioavailabilities of quercetin-3-glucoside and quercetin-4'-glucoside do not differ in humans. The Journal of Nutrition, 130(5), 1200-1203.

https://doi.org/10.1093/jn/130.5.1200

35. Peng, K.Z., Zhang, S.Y., Zhou, H.L. (2016). Toxicological evaluation of the flavonoid-rich extract from Maydis stigma: Sub- chronic toxicity and genotoxicity studies in mice. Journal of Ethnopharmacology, 192,161-169.

https://doi.org.10.1016/j.jep.2016.07.012

36. Pilaczynska-Szczesniak, L., Skarpanska-Steinborn, A., Deskur, E., Basta, P., Horoszkiewicz-Hassan, M. (2005). The influence of chokeberry juice supplementation on the reduction of oxidative stress resulting from an incremental rowing ergometer exercise. International Journal of Sport Nutrition and Exercise Metabolism, 15(1), 48-58.

https://doi.org/10.1123/ijsnem.15.1.48

37. Pinacho, R., Cavero, R., Astiasarán, I., Ansorena, D., Calvo, M. (2015). Phenolic compounds of blackthorn (Prunus spinosa L.) and influence of in vitro digestion on their antioxidant capacity. Journal of Functional Foods, 19, 49-62. https://doi.org/10.1016/j.jf.2015.09.015

38. Re, R., Pellegrini, N., Proteggente, A., Pannala, A., Yang, M., Rice-Evans, C. (1999). Antioxidant activity applying an improved $\mathrm{ABTS}^{\bullet+}$ radical cation decolourization assay. Free Radical Biology \& Medicine, 26(9-10), 1231-1237. https://doi.org/10.1016/S0891-5849(98)00315-3

39. Renfrew, J.M. (1973). Palaeoethnobotany: The Prehistoric Food Plants of the Near East and Europe. Methuen, London, UK.

40. Salahshoor, M.R., Mohammadi, M.M., Roshankhah, S., Najari, N., Jalili, C. (2019). Effect of Falcaria vulgaris on oxidative damage of liver in diabetic rats. Journal of Diabetes and Metabolic Disorders, $18(1), 15-23$.

https://doi.org/10.1007/s40200-019-00385-3

41. SPSS version 17.0 (SPSS Inc, Chicago, IL). Available at: https:// www.hks.harvard.edu/.../A\%20SPSS\%20Manuals/SPSS\%2.

42. Squillaro, T., Cimini, A., Peluso, G., Giordano, A., Melone, M.A.B. (2018). Nano-delivery systems for encapsulation of dietary polyphenols: An experimental approach for neurodegenerative diseases and brain tumors. Biochemical Pharmacology, 154, 303-317.

https://doi.org/10.1016/j.bcp.2018.05.016

43. Teng, H., Chen, L. (2019). Polyphenols and bioavailability: an update. Critical Reviews in Food Science and Nutrition, 59(13), 2040-2051.

https://doi.org/10.1080/10408398.2018.1437023

44. Tietze, F. (1969). Enzyme method for quantitative determination of nanogram amounts of total and oxidized glutathione. Analytical Biochemistry, 27, 502-522.

https://doi.org/10.1016/0003-2697(69)90064-5

45. Wang, W., Sun, C., Mao, L, Ma, P., Liu, F., Yang, J., Gao, Y. (2016). The biological activities, chemical stability, metabolism and delivery systems of quercetin: a review. Trends in Food Science \& Technology, 56, 21-38.

https://doi.org/10.1016/j.tifs.2016.07.004

46. Yuksel, A.K. (2015). The effects of blackthorn (Prunus spinosa L.) addition on certain quality characteristics of ice cream. Journal of Food Quality, 38(6), 413-421.

https://doi.org/10.1111/jfq.12170

Submitted: 30 April 2020. Revised: 14 July, 18 September, and 29 September 2020. Accepted: 30 September 2020. Published on-line: 9 September 2020. 